\title{
"YA, YA SE ABREN LAS FLORES»: LA LÍRICA DE SANTA TERESA EN LA HISTORIA LITERARIA DE LA MÍSTICA CRISTIANA
}

\author{
POR \\ LUIS M. GIRÓN NEGRÓN ${ }^{1}$ \\ Harvard University
}

\section{RESUMEN}

Son muy pocos los místicos cristianos en la Edad Media occidental que han recurrido al verso como vehículo expresivo: una anomalía histórica si se compara, por ejemplo, con la centralidad de la poesía strictu senso en la historia literaria del sufismo árabe y persa. La primera mitad de la charla ofrece una valoración de conjunto sobre la lírica de Santa Teresa en la historia literaria de la mística cristiana, enmarcada por referencias selectivas a sus exiguos precursores en el siglo XIII (Mechtild de Magdeburg, Hadewijch de Brabante, Jacopone da Todi y Richard Rolle) y con la literatura amatoria hispánica como telón de fondo. La segunda mitad de la presentación ilustra la estética de la Santa con una lectura de su glosa lírica al Cantar de los Cantares 2,16: «Dilectus meus mihi et ego illi».

PALABRAS CLAVE: mística cristiana; Teresa de Ávila; poesía mística.

\section{"THE FLOWERS ARE BEGINNING TO BLOOM, YES THEY ARE»: SAINT THERESA'S POETRY IN THE LITERARY HISTORY OF CHRISTIAN MYSTICISM}

\begin{abstract}
Recibido/Received 03-04-2018

Aceptado/Accepted 14-01-2020
\end{abstract}

There are very few Christian mystics in the Western Middle Ages that resort to verse as a means of expression in their writing, an anomaly if compared, e.g., to the centrality of poetry strictu senso in the literary history of Arabic and Persian Sufism. The first half of this study offers a comprehensive evaluation of Teresa of Ávila's body of poetry - the converso Carmelite reformerwithin the literary history of Christian mysticism, all of it set in contrast with San Juan de la Cruz's poetry, framed by selective references to her few precursors in the 13th and 14th centuries (Mechtild de Magdeburg, Hadewijch de Brabante, Jacopone da Todi and Richard Rolle), and with Hispanic love literature as a secular comparandum. The second part will showcase Saint Teresa's aesthetics in her mystical theology with a close reading of her lyric gloss on Song of Songs 2,16, "Dilectus meus mihi et ego illi».

KEY WORDS: Christian mysticism; Theresa of Avila; mystical poetry.

Cómo CITAR ESTE ARTículo / CITATION: Girón Negrón, Luis M. 2020. «"Ya, ya se abren las flores": la lírica de Santa Teresa en la historia literaria de la mística cristiana». Hispania Sacra LXXII, 146: 409-426. https://doi.org/10.3989/hs.2020.029

A Alberto Figueroa con cariño y gratitud en este quinto centenario teresiano

D'être toujours moins que ce que vient par lui et permet une genèse, le poème mystique a rapport avec le rien qui ouvre un à venir et, plus précisément, avec ce seul mot "Yahvé» par quoi ne cesse de pouvoir se nommer ce qui fait partir.

Michel de Certeau ${ }^{2}$

I: SANTA TERESA A LA SOMBRA DE SAN JUAN: ¿POETA O VERSIFICADORA?

Hay comparaciones que ofuscan la valoración literaria de la lírica teresiana, presupuestos infundados que la desenfocan. Entre los hispanistas que se dedican al Siglo de Oro español, dos tendencias suelen sesgarla: el contraste valorativo de su lírica con la poesía sanjuanista y la apreciación estética de su prosa en detrimento de sus versos.

\footnotetext{
1 giron@fas.harvard.edu / 
No extraña, por ejemplo, que las coplas de Santa Teresa pudieran palidecer ante una crítica encandilada con los versos delirantes de San Juan. "San Juan es un gran poeta y Teresa no más que una versificadora»: así afirmaba de forma taxativa Helmut Hatzfeld (1976a, 170) al proponer sendas tipologías de la poesía mística que oponían la densidad conceptual del teólogo con la pura emotividad de la escritora en una caracterización insostenible de lo masculino y lo femenino. En fechas más recientes, un ilustre sanjuanista también declara sin ambages: "Ya Santa Teresa, que trataba de hacer algún pinito poético, ...no tenía buena madera para ello... $»^{3} \mathrm{E}$ incluso un lector de la santa que conoce a fondo su obra contrapone en un clásico estudio la 'poesía-mística-en-estado-puro' en los tres carmina maiori del fraile de Fontiveros con cierta propensión teresiana a la pedagogía espiritual, rayana al de su didactismo en prosa, que le parecía menoscabar la 'pureza mística' de sus versos, incluso aquellos que, según él, habían sido los únicos nacidos bajo el impulso arrollador de un trance contemplativo. ${ }^{4}$

Parte del problema deriva de tomar ad litteram a la misma santa al afirmar "no soy poeta» en su Libro de la Vida: un aserto comprensible (el tópico de la humildad, la captatio benevolentiae), pero que exige matización. ${ }^{5}$ Tampoco sorprende que en el siglo XIX un erudito desorientado cuestionara por rústicos, vulgares o dicharacheros la autoría teresiana de algunos de sus villancicos. ${ }^{6} \mathrm{Ni}$ extraña tristemente la atención dispar que han recibido sus respectivos poemarios en la bibliografía crítica. En 1942, Dámaso Alonso le consagra un estudio histórico-literario a la poesía de San Juan en la línea iniciada por Jean Baruzi y su clásica monografía de 1924: hito temprano de una tradición

3 La cita íntegra figura en el prólogo a los poemas de San Juan de la Cruz, incluidos en la edición conjunta de los poemarios de ambos carmelitas preparada por Alberto Barrientos y Vicente Rodríguez 2011 115: "Ya Santa Teresa, que trataba de hacer algún pinito poético, aunque no tenía buena madera para ello, gozó escuchando parte de las poesías de su senequita y ella misma llevó al convento de Medina del Campo parte de las canciones del Cántico espiritual...».

4 García de la Concha 1978, 329, todo en el marco del último capítulo que consagra al corpus íntegro de la lírica teresiana (1978, 317-376).

5 Este aserto figura en el Libro de la Vida 16, parte de un pasaje $(16,3-4)$ que discutiremos más abajo con cierto detalle. Se van a citar los poemas teresianos según la edición conjunta de Barrientos y Rodríguez antes citada (2011) y el resto de las obras teresianas según la edición de Efrén de la Madre de Dios y Otger Steggink para la BAC (1986), pero también se consultará la edición dirigida por Alberto Barrientos 2000.

6 «Algunos de ellos me inspiran sospechas acerca de su legitimidad. Creo que más bien serían villancicos cantados por las monjas que no escritos por Santa Teresa. El villancico que remite a su hermano D. Lorenzo es conceptuoso, en voces comedidas, y su estilo análogo al que usa en otras poesías, que indudablemente son de su pluma; pero esas coplas de Gil y Pascual son tan estrafalarias, los conceptos tan bajos, las palabras tan toscas, que propiamente no son más que coplas de papel de ciego, que en nada se parecen a las otras composiciones de Santa Teresa. Quizá las cantara con sus monjas la misma Santa por ser vulgares en su país, y de ahí infirieran las copiantes que ella era la autora, puesto que componía otros» (Vicente de la Fuente 1881, 3 xxvi). Ya en el siglo XX se descubrieron versiones o fragmentos autógrafos para tres de estos villancicos teresianos de aire pastoril: Pastores que veláis, Al nacimiento del Redentor y iOh!, dichosa tal zagala véase abajo-. venerable. ${ }^{7}$ Pasarían décadas, en cambio, sin intentos equiparables de estudiar en su conjunto los poemas teresia$\operatorname{nos}^{8}$ y ninguno de ambiciones exhaustivas que estuviera a la altura crítica, por ejemplo, de la insuperable lectura que hace Rafael Lapesa (1988) de Vuestra soy, para Vos nací. Aun cuando ambos místicos abrevan en los cauces expresivos de una misma tradición oral -el caso de sus respectivas glosas a Vivo sin vivir en mí- no ha dejado de entorpecer la apreciación formal de la obra teresiana ese contraste machacón entre las raíces populares de la abulense y la cultura letrada de su senequita, los intentos por dirimir quién pudo influir en quién y los escarceos concomitantes de sus biografías con miras a determinar qué trances extáticos pudieran dar la putativa clave de lectura de ambas composiciones. ${ }^{9}$

Si resulta cuesta arriba valorar su poesía con los versos de San Juan como telón de fondo, no es menos arduo reseñar el arte de su lírica en el marco abrumador de su prosa. Teresa tenía, sin duda, una facilidad extraordinaria para el verso y para el canto. Así lo sugieren varios testimonios tanto propios como ajenos de las innumerables coplas que escribía e improvisaba, ya fuera al alimón de sus vivencias religiosas o al de los hitos y efemérides de la vida conventual para alegrar a sus monjas. Pero los pocos poemas que nos han llegado de autoría suya indiscutible - no más de veintinueve- representan una fracción exigua de su vasta producción textual. La vocación literaria de la santa se volcó incontenible en el corpus variopinto de sus escritos en prosa. Una obra nutrida, variada y muy completa -impregnada además con una voz imparangonable- que la crítica ha celebrado, entusiasta, por su 'elegancia desafeitada' en palabras de fray Luis de León. ${ }^{10} \mathrm{Y}$ no solo se celebran sus escritos como cumbre de todo un estilo anti-ciceroniano -ese 'escribir como se habla' tan cotizado por los humanistas cristianos a partir de Juan de Valdés - mas por la profundidad teológica, la capacidad expositiva, la penetración sicológica y el derroche imaginativo que entrañan, frutos de una inteligencia que - como mujer y conversa - intenta disimular de cara a la Inquisición. ${ }^{11}$ No sorprende, pues, que los panoramas históricos de la literatura áurea, deslumbrados por su prosa, releguen a un puesto secundario la valoración de sus versos.

Ninguna de estas tendencias ha supuesto un impedimento absoluto para una crítica perspicaz. Sus más sofisticados

\footnotetext{
7 Repasamos para este estudio la tercera edición del libro de Alonso 1958 y la tercera edición del estudio de Baruzi 1999. Importante visión de conjunto de su obra literaria en Thompson 2003.

8 Los esfuerzos pioneros de Vega 1975 y, sobre todo, García de la Concha 1978 , 317-376, se remontan a los setenta, seguidos por el bellísimo ensayo de Morris 1986 con una excelente apreciación estética in toto. Reciente estado de la cuestión sobre los poemas teresianos en Álvarez 2002.

9 Este poema clásico ha recibido una atención nutrida que se inicia con el estudio comparativo de Hatzfeld 1976a antes citado, seguido por Vega 1975, 57-72, García de la Concha 1978, 341-355 y la dura crítica a Hatzfeld de Tomás Álvarez 1996c.

10 Apreciación frayluisiana de la prosa de Santa Teresa en su Carta-dedicatoria a la Madre Ana de Jesús que acompaña a la editio princeps de las Obras de Santa Teresa de 1588, texto reproducido en García 1991, 1: 904-914 (elegancia desafeitada p. 907).

11 Valoraciones de conjunto sobre el arte literario de la prosa teresiana en Márquez Villanueva 1983, Weber 1990 y el citado estudio de García de la Concha 1978. Estudio pionero sobre su experiencia como religiosa conversa en Márquez Villanueva 1968.
} 
lectores han sabido, por ejemplo, poner de relieve cómo ese instinto nato para una prosa abocada a la expresión oral la capacitó, en palabras de Morris, «to explore in the narrow confines of verse variations of diction and melody as she perfected her own personal rhetoric of apparently artless simplicity» $(1986,248)$. También se ha destacado esa economía sin desperdicio en la trabazón cuidadosa de sus versos, esas canciones exhortatorias que interpelan a la fibra emotiva de sus oyentes con la urgencia visceral de una fe inquebrantable, sin comprometer, por ello, su muy trabajada «armonía y claridad de composición» (García de la Concha 1978, 343). No hay mejor caracterización del arte de sus canciones místicas que este juicio de Rafael Lapesa $(1988,147)$ :

La sublimidad de los tres poemas citados los ha hecho ver solamente como expresión arrebatada de un alma en trance de experiencias inefables; pero también revelan dominio de un arte refinado, tanto en la versificación como en el estilo. Las paradojas suprarracionales del amor divino se canalizan en fórmulas y moldes que antes habían revestido la exteriorización verbal del amor humano.

Santa Teresa no es poeta culta en la línea italianizante que cultiva su hermano en la descalcez con majestuosa soltura, pero la exquisitez de su lírica responde a unas exigencias artísticas también muy logradas que comienzan a valorarse en sus propios términos y no en los de un puro subjetivismo hagiográfico o como nota erudita al calce de las loas balbucientes al santo fraile carmelita.

Quedan, con todo, lagunas sustanciales en el estudio de su lírica, mucho camino por desbrozar para una apreciación histórica de lo que aporta Teresa, en cuanto poeta, a la Weltliteratur. Todas las ediciones, incluso las más recientes, adolecen de lagunas e imprecisiones en su aparato crítico. Hay, además, otra perspectiva que ayuda a realzar lo innovador de su lírica, algo que atañe a ambos carmelitas, pero que suele pasar desapercibido por una tercera fuente de ofuscación potencial: la valoración insuficiente de sus poemas en la historia literaria de la mística cristiana.

En la primera mitad de este estudio, se ofrece una valoración de conjunto sobre la lírica de Santa Teresa enmarcada por referencias selectivas a sus exiguos precursores en los siglos XIII y XIV y con la literatura amatoria hispánica como telón de fondo. En la segunda mitad, se ilustra la estética de la Santa abocada a la teología mística con una lectura detallada de su glosa lírica al Cantar de los Cantares 2:16. Ambas reflexiones se inscriben, a su vez, en un enigma histórico que esbozamos a grandes rasgos a manera de prolegómeno y para el cual carecemos de una explicación inequívoca. ¿Por qué escasea la poesía stricto sensu en la literatura mística cristiana de la Europa occidental tardomedieval, la tradición que precede al brote del verso sacro en la escritura ascéticomística del Siglo de Oro español?

\section{II: LA POESÍA MÍSTICA CRISTIANA EN LA EUROPA TARDOMEDIEVAL}

Podría pensarse que la mística y la poesía siempre han ido de la mano en el cristianismo occidental, que los precursores medievales de nuestros carmelitas - máxime en la mística amatoria - también cultivaban la poesía para comunicar sus vivencias contemplativas y darles forma literaria a sus intuiciones teológicas. Si el amor humano ha servido de estímulo ancestral a la lírica en las ramas más diversas de la literatura mundial, ¿cómo no ha de serlo también, en las grandes tradiciones místicas de orientación teísta, el amor a Dios vivido con intensidad como experiencia íntima de un alma embelesada que se une con su Amado? La popularidad perenne de los versos más memorables de ambos santos entraña con frecuencia (incluso "desde esta ladera») una convicción íntima entre sus muchos admiradores de lengua española de que hay un vínculo natural entre la mística y la poesía con una trayectoria multisecular por ellos dos coronada.

Hay, después de todo, otras tradiciones místicas premodernas también centradas en la unión amorosa con Dios como summum bonum de la vida contemplativa que han privilegiado el recurso a la poesía como modalidad literaria de reflexión teológica. Tenemos a la mano el ejemplo iluminador de la mística islámica, que tantas comparaciones sugerentes ha suscitado con la obra de nuestros carmelitas gracias a los esfuerzos pioneros de Miguel Asín Palacios, ampliados por Luce López Baralt. ${ }^{12}$ A partir del siglo IX, casi todas las grandes figuras del sufismo clásico también enriquecieron los archivos literarios de la tradición árabe con versos ascéticos (zuhdiyya) y poemas místicos que aclimatan a lo divino la venerable qașída de prosodia khaliliana, las odas más cortas de tema amatorio (el ğazal), báquico (poesía khamriyya) o descriptivo (wașfiyya) e incluso las grandes innovaciones hispanomedievales como las muwaššahāt y los zéjeles. Despuntan en esta galería Rābi'a al-'Adawiyya de Basora (m. 801), a quien se le atribuyen los primeros versos conocidos de tema sufí; el egipcio Dhū'-n-Nūn al-Mișrī (m. 859); Yaḥya ibn Mu'ādh ar-Razī (m. 871); el maestro bagdadí del sufismo sobrio Junayd al-Baghdādī (m. 910); el mártir clásico del amor divino, al-Ḥusayn ibn Manșūr al-Ḥallāj (d. 922); el murciano Muḥyddin Ibn al-'Arabī (1165-1240), la figura más original y repercusiva del sufismo teosófico, con su poemario Tarjumān al-ašwāq; y el gran 'Umar ibn al-Fārị̣ (m. 1235), cuyas qașā'id (sobre todo su Tā'iyya o Naẓm as-sulūk y su Khamriyya) representan el máximo esfuerzo arabófono por volcar a lo divino las convenciones más acendradas de la poesía amatoria secular de corte clásico. Al pasar de la lengua coránica a los otros vernáculos del Islam premoderno a partir del siglo XI, la poesía adquiere un papel aún más preponderante en la expresión literaria de la mística sufí con la composición de luengas qașā'id, el favorecimiento de la lírica amatoria corta (los ğazales monorrimos representan el género poético por excelencia del sufismo persa) y el recurso pionero al mathnawī vuelto a lo divino, dísticos rimados en serie para épicas didáctico-alegóricas

12 Esta línea investigativa tiene como punto de partida un par de ensayos iluminadores de Asín Palacios 1933; 1946 (el primer ensayo reimpreso en 1992 [243-326]), que amplifica López Baralt en varios estudios -e.g. 1985; 1989; 1998. Destaca en el marco de este estudio el ensayo de López Baralt de 1989 que representa su primer esfuerzo comparativo por dilucidar la simbología de los siete castillos concéntricos del alma en Las moradas del castillo interior a la luz de un motivo sufí que cristaliza en las Maqāmāt al-qulūb de Abū-I-Hasan an-Nūrī de Bagdad (siglo IX) - véase su traducción española en López Baralt 1999. Cabe aclarar, por otra parte, que solo se ofrece aquí un contraste fenomenológico entre dos tradiciones distintas de poesía mística para realzar el enigma histórico literario que nos interesa. No se propone ni mucho menos la preeminencia del verso en la tradición sufí como presunta explicación para el brote quinientista de la poesía mística española en una línea correspondiente con estas tesis comparatistas. 
en verso narrativo. El panteón literario del sufismo persa -que incluye ab initio los versos intercalados por 'Abdullāh-i Ansārī (m. 1089) en su devocionario, el Munājāt, y el primer mathnawī de tema sufí, el Hadīqat al-haqīqat de AbūI-Majd Majdūd Sanā'î de Ghazna (m. 1131) - da cabida a los grandes poemas alegóricos de Farīduddīn 'Atțār (m. 1220): su Mușībatnāma, su Ilāhīnāmā, su Ušturnāma y el pináculo de la tradición, su majestuoso Manțiq ut-țair; al Diwān y al Mathnawī del máximo poeta de las belles lettres en persa medieval, Maulānā Jalāluddīn Rūmī (m. 1273), verdaderas enciclopedias en verso de todos los grandes temas de la mística amatoria sufi; y a los ğazales de Muhammad Šamsuddīn Ḥāfiz (m. 1389), "the most widely-copied, widely-circulated, widely-read, widely-memorized, widely-recited, widelyinvoked, and widely-proverbialized book of poetry in Islamic history" (Ahmed 2016, 32), cuya traducción alemana sirviera de inspiración para el West-Östlicher Divan de Goethe en 1809. Lo mismo podría afirmarse del turco, el urdu y los otros vernáculos indo-musulmanes en la historia literaria del sufismo moderno. ${ }^{13}$

Este panorama selectivo de la poesía clásica sufí basta para resaltar el fenómeno histórico que me intriga: su contraste apabullante con la escasez del verso en la literatura mística cristiana. A diferencia de los sufies, son poquísimos en la Edad Media los místicos cristianos de Occidente que han recurrido al verso como medio alterno de expresión literaria (¡no digamos ya primario!). Los que hay son extraordinarios e incluso innovadores, pero no llegan a la media docena, poco más aun si añadimos figuras comparables del cristianismo oriental en Bizancio o en Armenia. ${ }^{14}$ Con la notable excepción de España, tampoco florece la poesía mística en la Europa ultrapirenaica en los albores quinientistas de la modernidad (hay que esperar hasta la segunda mitad del siglo XVII para toparnos con un poetamístico de la talla de Angelus Silesius). No hay en la mística cristiana una tradición acumulativa de figuras señeras que también compusieran a lo largo de siglos cuadernos de bitácora en verso a manera de periplos de la vida espiritual. ${ }^{15} \mathrm{El}$

13 Perspectiva sinóptica sobre la historia literaria de la poesía sufí en Schimmel 1982, con abundante bibliografía sobre los poetas principales de la tradición en sus diversas lenguas; véase también su clásica síntesis (Schimmel 1975) para una visión de conjunto sobre los presupuestos teológicos del sufismo, sus grandes figuras, obras principales y cómo engrana esta tradición con la historia religiosa del islam. Profunda revalorización del sufismo y del «madhab del amor» en la tradición islámica y del Islam mismo como concepto analítico en el capolavoro póstumo de Shahab Ahmed 2016.

14 Nos centramos en la rama occidental del cristianismo por razones histórico-literarias (i.e. la singular importancia de los vernáculos para los poetas místicos occidentales en una tradición cultural diglósica vertebrada por el latín como lengua clásica), pero no ignoramos, por ejemplo, la existencia de místicos-poetas extraordinarios de la talla del gálata San Simeón el Nuevo Teólogo (949-1022), autor de 58 Himnos al Amor Divino, o del monje San Gregorio Narek (951-1003) reverenciado merecidamente como el primer gran poeta de Armenia por su monumental Libro de las Lamentaciones, clásico cristiano de la literatura espiritual.

15 Para efectos de este ensayo, nos ceñimos a la tradición mística cristiana hasta el siglo XVI, pero nos consta, por ejemplo, que en el campo hispánico peninsular, los poemas de Santa Teresa y de San Juan de la Cruz forman parte de una tradición literaria multisecular que enriquece la vida religiosa de las órdenes contemplativas hasta el presente, como bien lo ejemplifica la excelente antología de GarcíaAsenjo y Soriano P.-Villamil 2004 dedicada a la poesía monástica verso como modus loquendi, como una manera de hablar y, sobre todo, como scène de l'énonciation (De Certeau 1982, 209-274), no abunda en la escritura mística del cristianismo occidental premoderno.

No es que falte sensibilidad poética o una capacidad imaginativa para el lenguaje figurado en la prosa literaria de la mística cristiana. He ahí los innumerables estudios sobre el imaginario poético de un San Gregorio Magno, un Bernardo de Claraval y sus émulos cistercienses, un Ricardo de San Víctor, una Catalina de Siena, un Meister Eckhart, un Heinrich Suso, una Julian of Norwich, una Margery Kempe o un Jan van Ruysbroek. Tampoco ha desatendido la crítica lo poético de la prosa tanto sanjuanista como teresiana (el centro de gravedad, en esta, del clásico estudio de García de la Concha). ${ }^{16}$ Bien decía Menéndez y Pelayo: "Todos nuestros grandes místicos son poetas, aun escribiendo en prosa ${ }^{17}$ No ignoramos tampoco la impronta sustancial de la mística amatoria cristiana en los archivos de la poesía medieval secular y religiosa (y viceversa), tanto en latín como en los vernáculos, con la lírica trovadoresca provenzal y sus epígonos franceses, germánicos o italianos a la cabecera, ni la abundante presencia de temas místicos que alientan con frecuencia la poesía litúrgica mediolatina y los grandes himnarios mariológicos. ${ }^{18} Y$ nos consta, por ejemplo, cómo el cisterciense Gérard de Liège, a mediados del siglo XIII, cita cancioncillas de amor en francés antiguo en su Quinque incitamenta ad Deum amandum ardenter para ilustrar los atributos de Dios como Amado, un gesto de apertura a la poesía del amor profano con raíces teológicas en la tradición mística y en un espíritu afín al que se aferran los poetas místicos que vamos a considerar. ${ }^{19}$ Podríamos subrayar de igual manera - un caso híbrido y singular - el magno poema en prosa que inserta Ramon Llull en su novela filosófica Blanquerna, el conmovedor Llibre d'amic et d'amat endeudado abiertamente con las paraules de sufies. Ni olvidamos, por supuesto, esa summa literaria de la civilización latino-cristiana que fue la Divina Comedia, con una representación alucinante del paraíso terrestre en la cumbre del Purgatorio, marcada a fuego por la nutrida exégesis cristiana del Cantar de los Cantares (Pertile 1998), o con esa dramatización poética del desiderium supernum que abarca la misma totalidad del Paradiso, fraguada en el crisol de esa tradición mística mediolatina que el poeta florentino

femenina en el siglo XX. También nos consta en este contexto la frondosa tradición del verso religioso en el mismo siglo XVI en la cual se inscribe la obra poética de Teresa y de la cual tenemos como ejemplo el Libro de romances y coplas del Carmelo de Valladolid editado por García de la Concha, Álvarez Pellitero y Sacramento 1982, con estudio reciente de Ugofsky-Méndez 2014. Los textos que incluye este cancionero rebasan el marco comparativo de este estudio, como también quedan fuera los de la rama hispanoamericana de esta veta, limitación que nos lleva a excluir igualmente los intentos por aunar a un Ernesto Cardenal y a otros contemporáneos bajo la rúbrica del verso místico, cfr. López Baralt 2012.

16 Estudio comparatista del recurso tanto teresiano como juancruziano a unas imágenes poéticas en su prosa mística en Girón Negrón 2014.

17 Discursos leídos ante la Real Academia Española en la pública recepción del doctor don Marcelino Menéndez Pelayo el día 6 de marzo de 1881, p. 40.

18 Véase Dronke 1968, esp. 57-97.

19 Véanse las calas iluminadoras de Dronke 1968, 59-63 basados en los textos extractados del ms. Vat. Reg. 71 por Wilmart 1933. 
tambien conocía al dedillo (Pertile 2005). Reconocemos, finalmente, el carácter restrictivo de nuestra circumscripción de "poemas místicos», conscientes de que, como bien me recordara mi querido colega Nicholas Watson, lo místico en cuanto rúbrica podría aplicarse de forma más flexible a toda una gama de poemas líricos de caracter devocional, meditativo o extático (anónimos en su mayoría, pero un puñado de autoría conocida como A Luve Ron de Thomas Hale), y que también se suelen dar exclusiones lamentables entre los estudiosos por un sesgo interpretativo que privilegia lo erótico-amatorio a expensas de lo espiritual sensu lato como esencia de lo místico. ${ }^{20}$

Pero, de nuevo, entre los místicos-escritores del cristianismo occidental se pueden contar con los dedos de una mano los que también escribieron poemas en un sentido estrecho (versos metrificados con sílabas contadas, esquemas de rima y estuches estróficos reconocibles) en el periodo que nos ocupa. Apenas un puñado de místicospoetas... o bien debiera decir místicos y místicas, pues estas constituyen casi la mitad de esta minúscula élite espiritual. Las mujeres despuntan como poetas en esta parcela estrecha de la literatura cristiana occidental, propiciado en gran parte por la centralidad misma que adquiere el vernáculo al carecer muchas de ellas de una formación en latín y también para vadear las consabidas restricciones eclesiásticas que les vedaba de jure toda actividad intelectual de carácter docente en materia de teología (Teresa, como bien se sabe, comparte toda una sociología literaria del vernáculo - y una teología en el vernáculo- con sus precursoras europeas). ${ }^{21}$

¿Quiénes integran este elenco? Podría abrirse esta nómina con San Francisco, cuyo Cántico de las criaturas se celebra justamente como acta de nacimiento de la literatura italiana en su vernáculo umbro. Pero fuera del Poverello, son apenas cuatro los místicos-poetas del cristianismo occidental premoderno que resaltan en esta criba, tres escritores en el vernáculo que vivieron en el siglo XIII -Jacopone da Todi, Hadewijch de Brabante y Mechtild de Magdeburg- y un gran místico inglés del siglo XIV que escribía en latín e inglés - Richard Rolle-.

El franciscano Jacopone da Todi (ca. 1236-1306) -el mayor poeta religioso de Italia anterior a Dante- es la única figura de relieve en la mística cristiana que recurre casi exclusivamente a la poesía como vehículo literario. ${ }^{22}$ Se conservan 92 laude de autoría indiscutible en su vernáculo umbro: baladas de tema sacro con una diversidad de esquemas populares de rima,

20 Comunicación personal del 7 de abril de 2015 (una perspectiva iluminadora de cara, por ejemplo, a la debatida caracterización de los versos religiosos de un fray Luis de León en relación con la tradición mística de corte clásico). Le agradecemos también a nuestro colega que, antes de su publicación, nos facilitara, como muestra, algunos fragmentos líricos de una oración que figura en el Liber florum celestis doctrine de John de Morigny (siglo XIV), obra que puede ahora consultarse en la edición y estudio que acaba de preparar con Claire Fanger (Fanger y Watson 2015).

21 Sobre las místicas cristianas en la Edad Media occidental, véanse los estudios clásicos que Bynum $(1987 ; 1992)$ y la crítica que han inspirado (Watson 1999) y la perspectiva de conjunto que ofrece McGinn sobre las figuras señeras de la mística femenina en las secciones correspondientes de sendos volúmenes (McGinn 1998; 2012); sobre las mujeres escritoras del medioevo occidental en general, véase también el importante estudio de Dronke 1984.

22 Para una visión sinóptica de Jacopone da Todi como místico, Ruh 1993, 473-485 y McGinn 1998, 125-131. estrofa y versificación que incluyen lo zejelesco. ${ }^{23}$ Se celebran sus laude no tanto por la musicalidad de sus versos ni por lo fantasioso de sus imágenes (elementos ajenos a su estética), mas por lo vívido y directo de su lenguaje -esa voz poética del homilista impaciente que rezuma urgencia ascética; también por la intensidad desgarradora de sus poemas autobiográficos (escribió verdaderas joyas de la literatura carcelaria medieval) y por la complejidad imaginativa con que aborda el tema central de su teología mística: el poder avasallador del amor divino, capaz de aniquilar el alma desbordada por los trances y arrobamientos del éxtasis unitivo. Su colorista trayectoria religiosa - el notario de pueblo que al enviudar vive una experiencia intensa de conversión (sobre todo al descubrir que su esposa Vanna llevaba puesto un cilicio); el loco itinerante por diez años que se vuelve franciscano, inmerso en las disputas de espirituales y conventuales; el defensor de los espirituales contra Bonifacio VIII cuya adhesión a los Colonna y al Manifiesto de Longhezza (1297) culmina con el sitio de Palestrina, su encarcelamiento en Todi en 1298 y su eventual exoneración en 1303 , tres años antes de morir - todo esto marcó a fuego la crónica poética de su vida espiritual- $-{ }^{24} \mathrm{El}$ poemario de Jacopone, que ya gozaba de una traducción castellana publicada en Lisboa en 1576 (casi seguramente no la primera), dejó huella discernible en la lírica religiosa hispánica desde fechas tempranas, con fray Ambrosio de Montesino a la cabecera, quien lo leyó en su original (cfr. su Cancionero de diversas obras de nuevo trovadas, editio princeps de 1508 en Toledo). Ya sugirió Orozco Díaz en su momento que, a la sombra de Jacopone, la poesía cantada a lo divino de los franciscanos en Castilla pudo servir de inspiración para la lírica conventual carmelitana (Orozco Díaz 1994, 157-161).

Prácticamente desconocidas en la España del siglo XVI, despuntan, por otra parte, las dos beguinas susodichas del siglo XIII y su vuelta a lo divino del fin'amour provençal, el minne de la lírica germánica en lo que una scholar designa la mystique courtoisie (Newman 1995, 137-167) pero que McGinn rubrica con mayor precisión como el «courtly mode of mystical language» (1998, 169). Ambas conjugan, con matices diferenciales, la exégesis místico-monástica del Cantar de los Cantares con los moldes expresivos de la literatura secular del amor cortés, sendos esfuerzos por articular - tanto en prosa como en verso- sus innovadoras contribuciones a una teología mística del amor divino. Hadewijch de Brabante, cabeza de una comunidad de beguinas en el segundo cuarto del siglo XIII, tiene una vasta cultura literaria, con una obra compleja en neerlandés medio que incluye un libro de visiones en prosa, un epistolario didáctico y dos colecciones de poesía: cuarenta y cinco poemas estróficos (Strophische Gedichten) inspirados por la lírica culta de los

23 Hemos seguido la edición crítica de Mancini 1980 (reproducción de su editio maior de 1974). Existe otra edición moderna de sus laude y demás escritos de Ageno 1953 y una edición de Menestò 1979 solo de los textos latinos que se le han atribuido. La enumeración de las laude en la edición de Mancini se basa en el orden que tienen en los manuscritos más antiguos por él compulsados, mientras que Ageno sigue la numeración tradicional establecida según criterios temáticos en la editio princeps de Francesco Bonaccorsi (Firenze 1490). Hemos seguido la numeración de Mancini al citar las Laude, pero puede consultarse su índice del laudario (Mancini 1980, 371-374) para su correspondencia puntual con la de Bonaccorsi.

24 Esbozo biográfico en Underhill 1919; excurso actualizado en Peck 1980. 
trouvères en el norte de Francia y dieciseis poemas en dísticos rimados en serie (Mengelgedichten) a guisa de cartas versificadas de orientación didáctica. Sus Strophische Gedichten aclimatan el lenguaje poético, la estructura formal y los temas clásicos de la lírica trovadoresca secular con miras a reorientar hacia Dios el ideal cortés del servicio amoroso, cifrado de forma exquisita en esa ubicuidad textual del minne (el amor) personificado. ${ }^{25}$

La beguina Mechtild de Magdeburg vivió, en cambio, en la segunda mitad del siglo XIII. Lo poco que se sabe de ella - su nacimiento hacia 1208; el que se hiciera beguina en 1230 , en una capacidad dirigente equiparable a la de Hadewijch; o su incorporación, ya en la vejez, a la comunidad cisterciense de Helfta hacia 1272- se colige de su única obra, que compone, alentada por su confesor - el dominico Enrique de Halle- entre 1250 y 1280: los siete libros de Das fliessende Lichte der Gottheit (de ahora en adelante $F L G){ }^{26}$ Mechtild profesa un carácter instrumental en su redacción, cuya autoría remite sin paliativos a la inspiración directa de Dios mismo: ${ }^{27}$ nueva «Biblia» de la mística amatoria, a caballo entre la prosa y el verso, lo confesional y lo didáctico, el soliloquio y los diálogos, toda en el vernáculo. El prosimetrum original en medio bajo alemán se ha perdido. Solo se conservan una traducción íntegra de mediados del siglo XIV al medio alto alemán y una traducción latina de sus primeros seis libros hecha por los dominicos de Halle hacia 1290. Pero la versión en Mittelhochdeutsche recoge con gran fidelidad la diversidad de esquemas poéticos intercalados en la obra - poemillas cortos de sabor popular, lírica trovadoresca a lo divino, alegorías más sesudas y complejas que engarzan la prosa con el verso, poemas dialogados, adivinanzas en verso- aunados todos por la intensidad de su imaginería erótica, el favorecimiento de la catafasis en su representación de la divinidad y un acercamiento más matizado que el de Hadewijch al lenguaje incandescente del amor cortés. ${ }^{28}$

Finalmente, el ermitaño Richard Rolle (ca. 1300-1349) fue el místico inglés más leído en Europa a lo largo de la baja Edad Media. Educado en Oxford, abandona la carrera para dedicarse de lleno a la vida eremítica, pero en sus últimos veinte años parece haber llevado un ritmo de vida más itinerante, periodo durante el cual compuso el grueso de su vasta obra y en el cual también sirvió de asesor espiritual para religiosas como la anacoreta Margaret Kirkeby y las monjas cistercienses de Hampole. El corpus nutrido de este prolífico escritor consiste mayormente de comentarios bíblicos y tratados místicos en prosa y en latín (Incendium amoris,

25 Perspectivas literarias sobre sus poemas estróficos en De Paepe 1967; Reynaert 1994; Dronke 1996, 81-83; visión de conjunto sobre su teología mística en Ruh 1993, 158-225 y McGinn 1998, 200-222. Edición completa de sus obras de Van Mierlo 1924-1925; 1942; 1947; 1952 y nueva edición de los Strophische Gedichten de Rombauts y De Paepe 1961 que citaremos en este estudio.

26 De aquí en adelante se darán en las citas los números pertinentes del libro y capítulo en FLG, seguidos por los números de página y líneas en la edición crítica de Neumann 1990-1993.

27 "Dis buoch sol man gerne enpfan, wan got sprichet selber dú wort ... 'Eya herre got, wer hat dis buoch gemachet?' 'Ich han es gemachet an miner unmaht, wan ich mich an miner gabe nút enthalten mag'...» (Neumann 1990-1993, 1: 4-5, líneas 1-2, 8-9).

28 Perspectivas de conjunto sobre su pensamiento místico en Ruh 1993, 245-292 y McGinn 1998, 222-244; véase también el estudio introductorio de Frank Tobin en su traducción inglesa (Tobin 1998, 1-27).
Emendatio Vitae, Contra Amores Mundi, etc.) para monjes y clérigos, pero también expuso su mística afectiva en obras didácticas y devocionales en su vernáculo dirigidas sobre todo a religiosas (The Form of Living, Ego Dormio, un comentario en el vernáculo al Salterio). Escribió además - lo que aquí nos atañe-composiciones líricas en ambas lenguas: i.e. tiene un poema devocional en latín (Canticum amoris), un puñado de poemas líricos exentos y algunos poemas insertos en otros opúsculos (e.g. los fragmentos líricos intercalados en una epístola para monjas, Ego Dormio). Sus versos líricos encarnan tanto en su métrica como en su contenido uno de los tres pilares de la mística afectiva de Rolle: la experiencia extática del amor divino como canor, como fruición jubilosa en el canto amatorio que es trasunto del celeste (e.g. «If pou wil loue, pan may pou synge to Crist in melodye; / the loue of hym ouercometh al pynge; in loue lyve we and dye» o "Say to hym day and nyght: 'When may I negh pe nere? / Wisse me to pi right, thi melody for to hire'»)..$^{29}$

Este cuarteto de poetas místicos apenas constituye una tradición continua de escritura literaria en la que pudieran inscribirse como deudores nuestros santos carmelitas. No es como en la historia literaria del tașawwuf medieval, donde las tradiciones árabe, persa, turca e indo-musulmanas de la poesía sufí se concatenan de forma estrecha en líneas acumulativas de transmisión directa. No hay solución de continuidad histórica entre los esfuerzos literarios de Jacopone, Hadewijch, Mechtild y Rolle en los siglos XIII-XIV y nuestros carmelitas en el siglo XVI. Las fuentes en que abrevan ambos para sustanciar su teología mística no son los poetas medievales susodichos y los modelos poéticos que emulan, tanto cultos como populares, tampoco hunden sus raíces - con la posible excepción del Jacopone romanceado- en las aportaciones pioneras de este cuarteto a sus respectivos vernáculos. Esto no impide, sin embargo, que los cuatro provean en su conjunto un telón de fondo muy útil para contrastes fenomenológicos que realzan a grandes rasgos el carácter singular de la lírica teresiana.

29 Ogilvie Thomson 1988, 44, vv. 67-68; 48, vv. 43-44. He aquí una síntesis insuperable del papel de la lírica para Rolle en el clásico estudio de Nicholas Watson: «Rolle uses poetry as a form for didactic and meditative writing because he is not a priest with an official concern for the salvation of his audience, but an eremitic lover of God, who sings mystical songs to him and who freely acts as a messenger, exhorting others to exercise their own inner freedom by striving to sing with them. Lyric verse provides him with an alluring vehicle for inviting his readers to follow not merely the commandments of God but his counsels - to embark on the way of perfection by means of love, abandoning the world and embracing Christ in the full sense implied by their status as coenobitic contemplatives. But in their song-like form, the lyrics also incarnate a message like that implicit in the lyrical prose Melos Amoris, or the inspired expository style of Super Lectiones Mortuorum: that the reader who takes the words to herself is participating (if imperfectly) in Rolle's own experience of love (canor), and is therefore moving closer to conformity both to Christ and to him. The lyrics are to be read at once as expressions of canor and as aids to the achievement of canor; both their message and their meter contribute to what Incendium Amoris calls 'ordered love' (148.7): a love patterned on Rolle's exemplary spiritual career, the climax of which is the attainment in this life of an experience of the ultimate pattern, the love-song of the blessed in heaven. For someone with Rolle's views about the spiritual life, verse seems an inevitable medium in which to call others to follow where he has gone before» (Watson 1991, 232-233). Junto al estudio de Watson, véase también la perspectiva sinóptica de McGinn 2012, 339-370 sobre su teología mística. 


\section{III: LA LÍRICA TERESIANA A LA LUZ DE SUS PRECURSORES LITERA- RIOS CRISTIANOS}

El paralelo más básico que ofrecen $a b$ initio es la centralidad misma de la tradición preexistente y el contrafactum sacro como esquemas de creación literaria: es decir, el aprovechamiento selectivo de modelos y temarios poéticos de la época, ya sean litúrgicos o seculares, para sus versos místicos. En términos puramente formales, ninguno de estos místicos inventa nuevas modalidades poéticas, ninguno crea cauces expresivos previamente inexistentes en la historia literaria de sus vernáculos. Todos los esquemas métricos que adopta Jacopone gozaban de modelos preexistentes entre los precursores de la lauda-ballata umbra y toscana. Los Strophische Gedichten de Hadewijch contrahacen en clave mística el abanico de predilecciones formales que derivan de la cansó amatoria de origen provenzal, modelo cultivado por los trouvères del norte de Francia y los minnesänger germánicos, los mismos que le inspiran, por ejemplo, el recurso a una evocación lírica de la naturaleza en la copla de apertura (el Natureingang), el cierre de sus poemas con una tornada, la preponderancia de una estructura tripartita y los esquemas interestróficos de concatenación. La lírica inglesa de Richard Rolle incluye secuencias de cuartetas monorrimas de arte mayor, dísticos rimados y cuartetas de arte menor con rima en los versos impares afines a los esquemas prosódicos de Middle English lyric, mientras que el Canticum amoris, con sus cuartetas monorrimas con cesura y doble rima interna, se inserta en una tradición poética de lírica devocional mediolatina de corte épico abocada a los grandes temas litúrgicos (la narrativa de la Pasión, el laus Mariae, etc.). En el ámbito hispánico, San Juan alterna entre los modelos cultos de la lírica italianizante, con el manejo virtuosista de la lira y el sexteto-lira, y los modelos populares del verso romancístico y cancioneril. Teresa, en cambio, se ampara casi exclusivamente en modelos estróficos y versificatorios de raíz popular, que cultiva con desenvoltura y creatividad. Privilegia las coplas y villancicos de estribillo, glosa y mudanza con octosílabos y hexasílabos - los versos más usados en la lírica popular hispánica a partir del siglo XV - y preponderancia de la rima consonante con esquemas semi-zejelescos, una veintena de poemas (el $80 \%$ de los de autoría teresiana casi segura) que se distinguen, según Navarro Tomás, «por la diversidad de sus combinaciones». ${ }^{30} \mathrm{~A}$ esto se añaden los casos singulares de sus dos canciones con estribillo y estrofas mixtas con octosílabos y pentasílabos (Pues nos dais vestido nuevo y $A$ la Exaltación de la Cruz) - lo más cercano a una innovación formal teresiana, si bien inspirada por las octavas medievales con alternancia de versos plenos y quebrados tetrasilábicos - y sus exiguos poemas sin mudanza que consisten puramente en redondillas octosilábicas (En la profesión de Isabel de los Ángeles), cuartetas hexasilábicas (A santa Catalina mártir), quintillas octosilábicas (Oh Hermosura que excedéis) y la famosa cancioncilla Nada te turbe en

30 «Los villancicos de Santa Teresa se distinguen por la diversidad de sus combinaciones; en su conjunto de unos veinte apenas se encuentran más de tres que coincidan en la misma forma. Sus rasgos revelan tradición arcaica en la preferencia por los estribillos de cuatro versos, en la abundancia de la rima consonante y en la libertad con que se reduce o aumenta el número de versos de enlace entre la mudanza y la represa del estribillo» (Navarro Tomás 1974, 236). tercetos pentasilábicos asonantados (si bien se ha cuestionado recientemente su autoría teresiana). ${ }^{31}$

Pero más central que la estructura es el temario en estas perífrasis religiosas de poemas amatorios. Teresa, grosso modo, se aúna aquí con las beguinas en la adecuación poética del amor cortés y sus imágenes para el verso religioso. Sus rifacimenti con glosa de cancioncillas amatorias a lo divino imbrican lo popular y lo cancioneril en un espíritu cercano al de sus precursores medievales. $Y$ es que los cinco poetas intuyen con Bernardo de Claraval y Ricardo de San Víctor un sustrato común de predisposiciones sicológicas y apetencias afectivas variopintas, bajo esa escala gradual de amores que va del humano al divino, tan solo diferenciables por su objeto. No extraña por ende que estos místicos gocen para sus versos de precursores comparables en los contrafacta devocionales de la poesía amatoria secular. Es archiconocido, por ejemplo, cuánto aprovecha San Juan el Boscán y Garcilaso a lo divino en manos de Sebastián de Córdoba, ese epítome ibérico de un petrarquismo espiritualizado cuyos versos denunciaba mi maestro Francisco Márquez Villanueva como una monstruosidad (San Juan era un poeta; Sebastián un poetastro). ${ }^{32}$ Teresa también compone sendas glosas con memorables contrafacta de temas cancioneriles (Vivo sin vivir en mí; Vuestra soy, para vos nací). Pero el recurso paralitúrgico a los rifacimenti de lírica profana se daba de igual manera en la poesía religiosa del siglo XIII. Son numerosos los casos documentados en la lírica devocional francesa y no sorprende que, en la misma línea, Mechtild de Magdeburg reescriba en el séptimo libro de FLG toda una canción de baile de aire tradicional atestiguada entre los poemas alemanes de tema profano en los Carmina Burana:

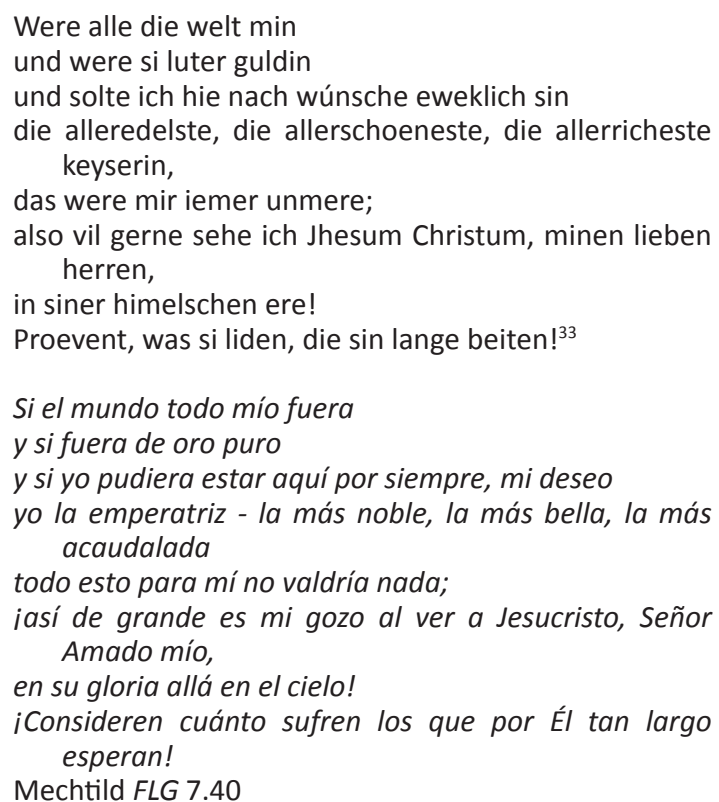

Uvere div werlt alle min von deme mere unze an den Rin, des wolt ih mih darben,

31 Sobre los problemas sustanciales para documentar la atribución de Nada te turbe a Santa Teresa, véase Vicente Rodríguez 20132014; 2015 quien propone a San Juan de la Cruz como posible autor.

32 Alonso 1958, 37-77.

33 Neumann 1990-1993, 1: 288-289.2-9. 
daz chunich ... von Engellant lege an minem arme $!^{34}$ Si el mundo todo mío fuera

desde el mar hasta el Rin,

a esto yo renunciaría

para que la Reina de Inglaterra pudiera tener en brazos. Carmina Burana 145a

Los poetas carmelitas y las dos beguinas comparten una proximidad instintiva con las convenciones temáticas, la simbología tradicional y la retórica conceptista avant la lettre de la poesía amatoria (en Jacopone se da en menor grado y en Rolle también se ha atenuado)..$^{35}$ Comparten, en esencia, esos temas clásicos del «courtly mode of mystical expression» que giran en torno al servicio incondicional y la entrega absoluta del amante caballeresco a un amor escurridizo y distante (amor de lohn), las metáforas bélicas de la lid espiritual, los juegos y equívocos del galanteo cortesano, la personificación poética de las facultades sicológicas, las pruebas y sufrimientos del verdadero amor, la fusión de valores éticos y estéticos, el intercambio de dones, las paradojas concomitantes del amor como martirio y la muerte de amor (tema medular de Vivo sin vivir en mí cuyas fuentes y paralelos la crítica ha estudiado con particular ahínco). ${ }^{36}$ Hadewijch y Mechtild aprovechan más a fondo este repertorio trovadoresco de temas amatorios que Santa Teresa, pero la abulense también desarrolla con intensidad motivos subsidiarios de abolengo cancioneril y petrarquista cuyas fuentes y paralelos la crítica ha ido rastreando. Un tema tan central de la lírica teresiana como ese anhelar ansioso la muerte de amor que es vida era moneda corriente en la tradición cortesana en la cual también abrevan Mechtild (e.g. FLG 1.2 «Disen gruos mag noch muos nieman enpfan, er si denne úberkomen und ze nihte worden. In disem gruosse wil ich lebendig sterben...»; 1.28 «Du darft mich nit me leren, ich enmag mich nit von der minne keren, ich muos ir gevangen wesen, ich mag anders nit geleben. Da si wonot, da muos ich beliben, beide an tode und an libe») $)^{37}$ y Hadewijch (SG 1.5.49-50 «Ay arme, ic en mach mi selven niet / doen leven noch sterven!»; 2.5.39-40 «Hine mach niet sterven dien Minne gheraket, / hare name amor es: vander doot»; 20.4.19-22 «Beter es die doet dan bitter leven. / Ay, minne, woudi ons volgheven / dat wi boven al worden verheven / dat nederheit es»; MG 10.51-54 «Die der minnen met minnen sal ghestaen, / al leuende moet hi die doet anegaen, om dat hem in minnen iet mochte ontbliuen / dat hi

34 Hilka, Schumann y Bischoff 1995, 470.

35 Sobre los ecos del amour courtois en Richard Rolle, véanse las calas pertinentes de Liegey 1956, 376-379, quien pone de relieve los motivos del amour courtois en las loas marianas del Canticum amoris y los otros textos en que también evidencia un conocimiento certero de las canciones amatorias de la época. Muestra, sobre todo, hasta qué punto ni siquiera Rolle es inmune al lenguaje de esta tradición amatoria, a pesar de argüir que los poetas del amor profano en su época no tenían la capacidad de cantarle al amor de Cristo (tema central de su propia lírica inglesa): "Quamquam namque muliercularum amatores cantica carnalis dilectionis blanda valde et mundanis amabilia componere satagunt, profecto in modum amantium Christum suavia non componunt» (texto del Melos amoris citado por Liegey 1956, 377).

36 Perspectiva sinóptica sobre el lenguaje y temario del amor cortés a lo divino en McGinn 1998, 168-171 y la nota 75 en la p. 404 Véase también Wainwright-deKadt 1980.

37 Neumann 1990-1993, 1: 9.40-42, 22.8-10. met arbeide mochte vercrighen.»).. ${ }^{38}$ Su hermoso Coloquio de amor entre Dios y el alma, tema religioso de larga historia literaria, también goza de sugerentes paralelos con los diálogos exquisitos que Mechtild deriva de la poesía amatoria cortesana, comenzando por el diálogo alegórico entre la Dama Amor (frouwe minne) y el Alma Reina (frouwe kúneginne) al principio de FLG. El estudio de estos motivos ofrece incluso comparaciones sugerentes con el mismo Jacopone, como es en la sexta estrofa de Vivo sin vivir mí el de ese anhelar ansioso la muerte de amor en los versos 5-6, que Hatzfeld yuxtapone con varios versos de la Lauda $89 .{ }^{39}$

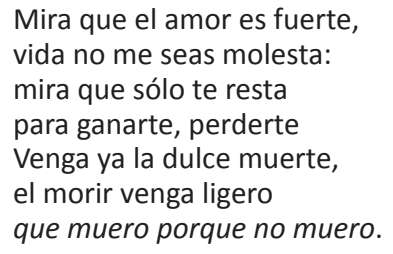

Mira que el amor es fuerte,

vida no me seas molesta:

mira que sólo te resta

para ganarte, perderte

Venga ya la dulce muerte,

el morir venga ligero

que muero porque no muero.
Amor, Amor, la morte t'ademando
Amor, Amor-lesù, si delettoso
ché moro en delettanza ...
Amor cui tanto abramo, fan'me morir d'amore!

Se podrían multiplicar, al igual que con Hadewijch, Mechtild, Jacopone e incluso Rolle, otros motivos literarios de época aprovechados por la Santa que comparte con obras diversas de temática tanto secular como religiosa. Baste un solo ejemplo de Vivo sin vivir en mí desatendido en la crítica: el letrero del amante en el corazón de la amada.

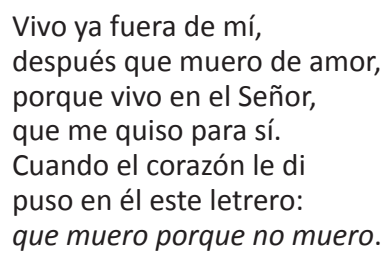

Este motivo poético (que reescribe un venerable topos neoplatónico ${ }^{41}$ estaba muy difundido en la literatura española del siglo XVI. En el coloquio pastoril Prendas de amor, el sevillano Lope de Rueda hace, por ejemplo, que la pastora Cinela le entregue al pastor Menandro «un corazón con un letrero esmaltado» con un letrilla de amor que comienza «Ya no me tengo más que dar, / pues te doy el coraçón...» (Canet 1992, 317). En un romance anónimo de tema morisco, también sale un moro de Granada con «un coraçón pintado, /

38 Selecciones de los SG en Rombauts y De Paepe 1961, 38, 44, 148; cita de los MG en Van Mierlo 1952, 48; estudio de este tema en la obra de Hadewijch en Reynaert 1976.

39 Citamos el texto de Jacopone según la edición crítica de Mancini 1980, 280-289 que le asigna el número 89; Hatzfeld (1976a, 176) lo identifica como Lauda 90 según la numeración correspondiente a la editio princeps de 1490 de Francesco Bonaccorsi.

40 Este tema se anticipa desde el comienzo de esta extraordinaria lauda mística (Mancini 1980, 280, vv. 3-10): "Arde et encende, nullo trova loco, / non pò fugir, però ched è legato, / si sse consuma como cera a ffoco, / vivendo mor, languisce stemperato; / demanda de poter fugire un poco, / et en fornace tròvasse locato. / Oimè, e o' so' menato a ssì forte languire? / Vivendo ssi è morire, 'n tanto monta l'ardore».

41 Véase el capítulo V de Serés 1996 sobre la inscripción de la amada en el alma del amado como topos poético. 
en el medio de su adarga» atravesado por una saeta y «con un letrero que dize, / 'Por ti mi vida y mi alma'»). Y en la Comedia Florinea de Juan Rodríguez Florián, publicada en 1554, dos personajes describen la representación de la Amistad en el Senado Romano como un mancebo «con la mano diestra enseñando el coraçón descubierto, del qual procedía un letrero matizado de fino oro que dezía: muerte, vida» ¿Qué hace Teresa con este leitmotiv? La santa lo reescribe a lo divino, en consonancia con el tema venerable de la escritura de Dios en el alma, motivo devocional que también evoca el mismo fray Jacopone:

\section{Dentro ce t'a<r>trov'escripto /}

che te escripse l'Amore, che non me deviss'escordare (en la edición de Mancini 73, 55-56: 217)

Pasando a comparar ahora su corpus lírico in toto con el de los otros poetas místicos, los contrastes de bulto con el de la santa se vuelven más pronunciados. El poemario teresiano, como habíamos dicho, apenas consta de veintinueve composiciones de autoría indiscutible o muy probable y una estela de canciones de dudosa autenticidad, desperdigadas en la pleamar de versos compuestos por sus hijas para alegrar la vida conventual a imitación de la santa. ${ }^{42}$ Ahora bien, este elenco apretado de poemas suyos que se conservan es mucho más reducido que el de casi todos sus precursores (lo mismo puede afirmarse del corpus poético sanjuanista, cuya fama prosperara en proporción inversa a su modesta extensión, apenas trece poemas). El contraste con Jacopone es obvio ya que el franciscano solo escribió en verso una antología sustancial de casi un centenar de laudes. Hadewijch y Mechtild también compusieron un número mucho mayor de poemas que Teresa, todos de tema místico centrados en el drama del amor divino, con una admirable variedad de estilos literarios y una diversidad vertiginosa de matices teológicos - una densidad conceptual y analítica - que Teresa relega a discusiones equiparables en su tratadística en prosa (San Juan también se ciñe a

42 La lista tentativa propuesta en la edición reciente de Barrientos y Vicente Rodríguez (2011) los divide grosso modo en tres categorías: 1- Poesías lírico-místicas (1) Vivo sin vivir en mí; (2) Mi Amado para mí; (3) iO hermosura que excedéis!; (4) Búscate en mí; (5) Vuestra soy, para Vos naci; (6) Nada te turbe; (7) Loa a la cruz redentora; (8) A la Exaltación de la Cruz; (9) Coloquio de amor; (10) Ayes del destierro; 2- Poesías festivas y hagiográficas (11) Pastores que veláis; (12) Al nacimiento del Redentor; (13) Ya viene el alba; (14) Vertiendo está sangre; (15) Villancico a la Natividad; (16) Sangre a la tierra; (17) En la fiesta de los Reyes; (18) A san Andrés apóstol; (19) A san Hilarión anacoreta; (20) A santa Catalina mártir; 3- Poesías didácticas y de vida religiosa (21) A la velación de la Hna. Isabel de los Ángeles; (22) A la vestición de Sor Jerónima; (23) En una profesión religiosa; (24) Ya no durmáis, no durmáis; (25) En la profesión de Isabel de los Ángeles; (26) A la gala gala de la religión; (27) Camino para el cielo; (28) Pues nos dais vestido nuevo; (29) iOh! dichosa tal zagala — también recogen en un cuarto apartado de 4- Poesías de dudosa autenticidad (30) Dichoso el corazón enamorado; (31) Caminemos para el cielo; (32) una versión glosada de Nada te turbe. La edición de Madre de Dios y Steggink 1986, 651-670 relega el Coloquio de amor a la lista de dudosas; recoge Caminemos para el cielo dos veces - una con estribillo bajo el título Hacia la patria entre las auténticas, la otra sin estribillo entre las dudosas, amén de una tercera variante soriana que titulan Monjas del Carmelo (la no. 31 de Barrientos y Vicente Rodríguez); y, aunque consideran suya la letrilla exenta de Nada te turbe, solo la reproducen seguida por la glosa de dudosa autenticidad. la prosa para explicitar su teología, si bien en el marco singular de inusuales comentarios a sus propios poemas). Rolle es el único que tiene una producción poética igual de reducida, comparable en sus dimensiones a las de los carmelitas y también como ellos en proporción comparable a una obra en prosa mucho más extensa. Pero el poemario teresiano, aunque pequeño, responde a un registro bastante amplio de fines religiosos y contextos de composición claramente diferenciables. Los poemas líricos de contenido místico se alternan, por un lado, con las composiciones ad hoc para las diversas fiestas que jalonan el fluir acompasado de la vida conventual (siete villancicos para el ciclo de la Navidad, la Circuncisión y los Reyes; una canción para la fiesta de la Exaltación de la Cruz; tres poemas votivos en honor a San Andrés, Santa Catalina y San Hilarión el anacoreta); por el otro, con los poemas devocionales de ocasión cuando sus hijas tomaban el velo o profesaban sus votos perpetuos. También hay referencias fugaces a la vida comunitaria de las beguinas en las obras de Hadewijch y Mechtild (e.g. la muerte de la hermana Hildegunda en la fiesta de Santa Bárbara en FLG 2:20 [Neumann 1990-1993, 1, 52-51]) y las laudes de Jacopone muestran a su vez una diferenciación temática entre poemas ascético-penitenciales y líricomísticos, con obras individuales asociables con fiestas y santos (sus cánticos de Navidad y sus poemas laudatorios a San Francisco y Santa Clara), amén de un puñado de laudes autobiográficas (sus poemas carcelarios, sus epístolas a Bonifacio y a fray Juan de Alverna). Algunos textos líricos de Rolle figuran en Ego dormio, un opúsculo epistolar destinado a la consejería espiritual de monjas, pero se desconoce el contexto compositivo de sus otros poemas. Teresa, sin embargo, siempre parece componer sus coplas al calor inusitado de momentos particulares, ya fueran experiencias íntimas o celebraciones conventuales, prodigando luminosas apostillas en verso al transcurrir de esos días que en sus libros y en sus cartas plasma ya por extenso. A diferencia de sus predecesoras e incluso del mismo Jacopone, gozamos en su caso con muchos más referentes textuales e históricos sobre la composición individual de varios poemas tanto en sus propios escritos como en las memorias de sus contemporáneos.

Tres de sus coplas festivas celebran, por ejemplos, hitos muy precisos en la vida religiosa de monjas particulares: una cancioncilla glosada con seis septillas para la velación de Isabel de los Ángeles en Medina del Campo en 1569, diez cuartetas para celebrar su profesión final dos años después en Salamanca en 1571 y una miniatura de tres versos (Buena ventura) para conmemorar la toma de hábito de Sor Jerónima de la Encarnación, sobrina del inquisidor Quiroga, en 1575 también en Medina del Campo.. ${ }^{43}$ Una antigua tradición del convento de Soria sugiere que su canción para la fiesta de la Exaltación de la Cruz, personalísima reinvención de los temas del himno Vexilla regis, pudo ser compuesta in situ durante una breve estadía para su décimoquinta fundación ${ }^{44}$ y que esas mismas monjas lo cantaron por primera vez poco después, casi un año antes de

\footnotetext{
43 Madre de Dios y Steggink 1977, 605 (Parte II, cap. 4, párrafo 370).

44 Sobre su estancia en Soria, véase Madre de Dios y Steggink 1977, 882-901 (Parte II, cap. 7, párrafos 553-562).
} 
su muerte, el 14 de septiembre de $1581 .^{45}$ Hay otras efemérides deliciosas que Teresa memorializa en verso, como son las coplas con estribillo de Pues nos dais nuevo vestido compuestas entre 1562 y 1567 en San José de Ávila, verdadera rogativa humorística - no exenta de picardíapara librarse de los piojos que habían infestado los ásperos vestidos de jerga de sus monjas, distrayéndolas durante la oración, y que van recitando a coro de celda en celda en un ritual de purificación. ${ }^{46}$

Ha habido, por otra parte, intentos resbaladizos (sugerentes sí, pero subjetivos) de establecer una cronología aproximada para aquellos poemas interpretados como transposiciones líricas de su vida religiosa, todo en puntual relación con la datación igual de tentativa de los trances extáticos, los arrobos, las visiones y hasta los momentos más desoladores de sequedad espiritual que jalonan y vertebran su extraordinaria autobiografía. Según Hatzfeld, por ejemplo, «tenemos la seguridad» de que Vivo sin vivir en mí había sido compuesta por Teresa poco después de un arrobamiento en Salamanca el 15 de abril de 1571, domingo de Pascua, al oír la canción a lo divino "Véante mis ojos, dulce Jesús bueno» cantada por la novicia Isabel de Jesús a coro con las monjas (Cuentas de conciencia 13a.1 [Madre de Dios y Steggink $1986,598])$, afirmación repetida con frecuencia en la crítica y en la tradición carmelitana, pero disputada vigorosamente por Tomás Álvarez ante la ausencia palmaria de fundamento histórico alguno: para este, es más probable que lo compusiera en Ávila en 1572 cuando estaba en la Encarnación. ${ }^{47}$ García de la Concha, quien se suscribe a la propuesta de Hatzfeld, propone incluso un orden tentativo de composición para los tres poemas teresianos que considera fruto de un trance extático, Mi amado es para mí que liga al inicio del desposorio místico, seguidos por Vivo sin vivir en mí y iO hermosura que excedéis! que brotaron, según él, «durante una sequedad pasiva subsiguiente a un limitado rapto unitivo, presagio del matrimonio místico habitual» (1978, 329-330). Mi amado es para mí, el poema que analizaremos al final de este ensayo, se asocia tradicionalmente con la famosa experiencia de la transverberación (que se suele datar hacia 1562), aunque ningún crítico se atreva a postular una datación exacta para estas coplas extraordinarias.

Hay que proceder con suma cautela en un ámbito tan especulativo y tan ajeno al quehacer histórico y filológico. Pero sus propios escritos nos asisten de forma explícita con la datación, el encuadre e incluso la exégesis de algunas de estas coplas místicas, fruto de su vida contemplativa. La enjundiosa carta a su hermano Lorenzo, escrita en Toledo

45 Vega 1975, 119-120, quien cita al respecto al P. Silverio; Barrientos y Vicente Rodríguez 2011, 41-42.

46 Episodio minuciosamente documentado por Madre de Dios y Steggink 1986, 258-260, II.1.38-39. La evocación del hábito infestado de piojos también figura en otras tradiciones ascético-místicas como indicio del estado de pobreza necesaria para la vida contemplativa: e.g. la definición de faqr ('pobreza') en la țarīqah sufí ejemplificada por al-Murta'iš an-Naysābūrī (m. 328 / 939) al describir el verdadero faqīr como «aquel a quien los piojos lo devoran y no tiene ni una uña con que rascarse» (alladhī ya'kuluhu al-qamalu wa-lā yakūn lahu zufrun yaḥukku bihi nafsahu), aserto citado por al-Sarrāj al-Ṭūsī en su Kitāb al-Luma' fi-l-tașawwuf (Nicholson 1914, 108 en la paginación árabe). Le agradecemos a John Zaleski esta referencia.

47 Hatzfeld 1976a, 171 y Álvarez 1996b 40-46, especialmente la nota 21 en la p. 44. el 2 de enero de 1577, abunda, por ejemplo, en detalles preciosos sobre la composición y diseminación de iO hermosura que excedéis a todas las hermosuras! (Carta 168 en la edición de la BAC [Madre de Dios y Steggink 1986, 10631067], párrafos 23, 35, 36-40).

Gran fiesta tuvimos ayer con el Nombre de Jesús; Dios se lo pague a vuestra merced. No sé qué le envíe por tantas como me hace, si no es esos villancicos que hice yo, que me mandó el confesor las regucijase, y he estado estas noches con ellas y no supe cómo sino ansí. Tienen graciosa sonada, si la atinare Francisquito, para cantar.

Esas coplas que no van de mi letra no son mías, sino que me parecieron bien para Francisco, que como hacen las de San Josef de las suyas, esotras hizo una hermana. Hay gran cosa de eso estas Pascuas en las recreaciones.

Pensé que nos enviara vuestra merced el villancico suyo, porque éstos ni tienen pies ni cabeza, y todo lo cantan. Ahora se me acuerda uno que hice una vez estando con harta oración, y parecía que descansava más. Eran ya no sé si eran ansí, y por que vea que desde acá le quiero dar recreación:

¡Oh Hermosura que excedéis

A todas las hermosuras!

Sin herir dolor hacéis

Y sin dolor deshacéis

El amor de las criaturas.

¡Oh ñudo que ansí juntáis

Dos cosas tan desiguales!,

No sé por qué os desatáis,

Pues atado fuerza dais

A tener por bien los males.

Juntáis quien no tiene ser

Con el Ser que no se acaba:

Sin acabar acabáis,

Sin tener que amar amáis,

Engrandecéis nuestra nada.

No se me acuerda más. ¡Qué seso de fundadora! Pues yo le digo que me parecía estava con harto cuando dije esto.

Dios se lo perdone que me hace gastar tiempo. $Y$ pienso le ha de enternecer esta copla y hacerle devoción; y esto no lo diga a nadie.

Doña Yomar y yo andávamos juntas en este tiempo. Déla mis encomiendas.

... va un cantarcillo a fray Juan de la Cruz, que me enviaron de la Encarnación. Diga que yo lo digo, que me cayó muy en gracia, para que cante Francisco a vuestra merced.

Se precisa allí que le hizo llegar algunos "villancicos» suyos (entre los cuales se incluye el de estas tres quintillas reproducidas al final de la carta) como gesto de agradecimiento por todas sus mercedes y que entretuvo a sus monjas con estas cancioncillas por petición de su confesor al celebrar el día anterior la fiesta litúrgica del Santo Nombre de Jesús. ${ }^{48}$ Añade que esos villancicos «tenían una graciosa sonada, si

48 En época de Teresa, todavía se celebraba la fiesta de la Circunsición del Señor el 1 de enero: i.e. en la octava de su nacimiento - cfr. Lucas 2,21-como lo exigía la ley judía, el mismo día en que los varones hebreos también recibían su nombre y que da pie a que el culto tardomedieval del Santo Nombre se asociara con dicha fiesta. Su celebración litúrgica en el calendario franciscano, que ya anticipaba San Bernardino de Siena como devoción privada, es aprobada 
la atinare Francisquito» - el hijo mayor de Lorenzo- «para cantar» (la centralidad de la música en Teresa merece un estudio aparte) y que acompaña este envío con poemillas en una letra distinta escrita por otra hermana, igual que suelen hacerlo las monjas de San José. Puntualiza, además, que compuso esta copla «una vez estando con harta oración» cuando andaba con doña Guiomar de Ulloa (por lo cual se ha propuesto 1560 como el año de su composición), que solo recordaba de memoria las tres estrofas aquí transcritas (si bien despliegan tal coherencia que algunos críticos consideran tener aquí el poema entero) y que está convencida de que su lectura va a enternecer a su hermano "y hacerle devoción» (profesión un tanto arriesgada por lo cual insiste al despedirse de que lo guarde en secreto). Aún más, en su próxima misiva a Lorenzo (17 de enero de 1577) - un extraordinario ejercicio de consejería espiritual en el que atiende a las dudas específicas que él tenía sobre su propia vida de oración - la santa comenta los últimos tres versos de la primera estrofa con miras a dilucidar, en alusión a la respuesta perdida, "lo que dice no entiende de la copla» sobre esa indolora "herida que da el amor de Dios en el alma» (Carta 174 en la edición de la BAC [Madre de Dios y Steggink 1986, 1073-1076], párrafos 8-9): singular instancia, si bien privada, en la que Teresa recurre, como San Juan, a comentar su propia poesía para el esbozo en clave fenomenológica de su teología mística:

De lo que vuestra merced me dice que ha tenido, no sé qué le diga, que cierto, es más de lo que entenderá y principio de mucho bien, si no lo pierde por su culpa. Ya he pasado por esa manera de oración y suele después descansar el alma y anda a las veces entonces con algunas penitencias. En especial si es ímpetu bien recio, no parece se puede sufrir sin emplearse el alma en hacer algo por Dios; porque es un toque que da al alma de amor, en que entenderá vuestra merced - si va creciendo - lo que dice no entiende de la copla; porque es una pena grande y dolor sin saber de qué, y sabrosísima.

$Y$ aunque en hecho de verdad es herida que da el amor de Dios en el alma, no se sabe adónde ni cómo, ni si es herida, ni qué es, sino siéntese ese dolor sabroso que hace quejar, y ansí dice

Sin herir dolor hacéis

Y sin dolor deshacéis

El amor de las criaturas

Porque cuando de veras está tocada el alma de este amor de Dios, sin pena ninguna se quita el que se tiene a las criaturas. Digo de arte que esté el alma atada a ningún amor (lo que no se hace estando sin este amor de Dios), que cualquiera cosa de las criaturas, si mucho se aman, da pena; y apartarse de ellas, muy mayor. Como se apodera Dios en el alma, vala dando señorío sobre todo lo criado, y aunque se quita aquella presencia y gusto (que es de lo que vuestra merced se queja, como si no huviese pasado nada cuanto a estos sentidos sensuales que quiso Dios darles parte del gozo del alma), no se quita de ella ni deja de quedar muy rica de mercedes, como se ve después, andando el tiempo, los efectos.

No hay poeta en la mística cristiana - ni Hadewijch ni Mechtild ni Jacopone ni Richard Rolle, ni el mismísimo San
Juan al vertebrar sus tratados comentando sus versos- que nos ofrezca un cuadro tan rico en detalles sobre el génesis y sentido de un poema suyo como fruto de la oración contemplativa, ni que evoque con tal vividez la sociología literaria del canto devocional en su propia comunidad religiosa. Pero tampoco ha habido esfuerzos equiparables de parear los poemas de estas figuras con una cronología conjetural de sus experiencias místicas (ni siquiera se ha dado el gesto típico que vemos en la bibliografía sanjuanista o teresiana de proponer una hermenéutica especulativa para los textos asociada con la taxonomía subyacente de sus arrobamientos). Este contraste hunde sus raíces en un hecho muy sencillo. No sabemos casi nada sobre las vidas de Hadewijch y Mechtild. Apenas hay datos personales colegibles de sus obras y tampoco tenemos fuentes biográficas externas que puedan echar luz sobre los pormenores relevantes de su vida religiosa como marco compositivo de su quehacer literario. En cuanto a Jacopone y su trayectoria vital, se sabe un poco más, aunque ofusquen las leyendas que lo aureolan: los datos exiguos que nos da de sí están dispersos en un puñado de poemas ascéticos y carcelarios de corte semi-autobiográfico. Carecemos, sin embargo, de pistas y referentes para el grueso de sus versos místicos. Algo parecido puede afirmarse de Rolle: se conocen algunos datos sobre su educación, su vida de ermitaño y su asociación subsecuente con religiosas, pero lo que sabe es muy poco, casi todo desgajado de sus escritos y prácticamente nada que pudiera echar luz alguna sobre las circunstancias compositivas de su lírica devocional. El caso teresiano, como vimos, es muy distinto. Se conoce muchísimo de su vida extraordinaria, tanto de su gesta pública en aras de la reforma como de ese itinerario íntimo hacia el castillo interior plasmado en sus escritos. Ya hemos visto lo mucho que se sabe de varios de sus poemas. Contamos incluso, pese a los problemas espinosos que entraña su transmisión manuscrita, con autógrafos teresianos de algunos versos. Tenemos de su puño y letra las últimas dos estrofas de Pastores que veláis en el convento de las carmelitas en Florencia, unos versos de iOh!, dichosa tal zagala custodiado por las descalzas de Génova y el texto íntegro de Al nacimiento del Redentor en dos fragmentos (uno también en Florencia, el otro en Savona), ${ }^{49}$ algo que no se da ni con Jacopone, ni con Hadewijch ni con Mechtild (como tampoco se da con el poemario de San Juan, a pesar de las correcciones autógrafas que sí se conservan en los poemas del códice de Sanlúcar de Barrameda).

Teresa ofrece además reflexiones explícitas sobre su estro poético y las circunstancias compositivas que ello implica. Es famoso el pasaje al que hemos aludido brevemente en el que niega ser poeta.

Vida 16,3-4 (Madre de Dios y Steggink 1986, 93-94)

...Ya, ya se abren las flores, ya comienzan a dar olor. Aquí querría el alma que todos la viesen y entendiesen su gloria para alabanzas de Dios y que la ayudasen a ella, y darles parte de su gozo, porque no puede tanto gozar. Paréceme que es como la que dice el Evangelio que querría llamar o llamaba a sus vecinas (Lc 15,6.9). Esto me parece debía sentir el admirable espíritu del real profeta David cuando tañía y cantaba con la arpa en alabanzas de Dios (2 Sam 6,14). De este glorioso Rey soy yo muy devota, y querría que todos los fuesen, en 
especial los que somos pecadores. ¡Oh, válgame Dios, cuál está un alma cuando está así! Toda ella querría fuesen lenguas para alabar al Señor. Dice mil desatinos santos, atinando siempre a contentar a quien la tiene así. Yo sé persona que, con no ser poeta, que le acaecía hacer de presto coplas muy sentidas declarando su pena bien, no hechas de su entendimiento; sino que, para más gozar la gloria que tan sabrosa pena le daba, se quejaba de ella a su Dios. Todo su cuerpo y su alma querría se despedazase para mostrar el gozo que con esta pena siente.

Teresa agavilla aquí los temas centrales de su inspiración religiosa como «trazadora de versos»: el deseo de comunicar las gracias divinas recibidas y el gozo que la sobrecoge como ímpetu visceral que la lleva al verso y al canto, su íntima afinidad con la figura del rey David (tan venerada en el Carmelo) que tañe su arpa y canta en alabanza impelido por el espíritu profético, el modelo evangélico del buen pastor que al hallar la oveja perdida se lo pregona a sus vecinos con un júbilo inenarrable, su carácter semi-improvisatorio ( «le acaecía hacer de presto») centrado en la efusión del sentimiento religioso («coplas muy sentidas») por inspiración divina como "desatinos» del amor extático. No hallaremos un texto afín a este "manifiesto poético» de la abulense para los dos poemarios de Hadewijch. Mechtild, por su parte, profesa sin escrúpulos su auto-percepción radical como portavoz privilegiada de los ipsissima verba de Dios a través de su libro, pero no abunda en detalles sobre el Sitz im Leben compositivo de sus interludios poéticos ni su estética subyacente. La poética teresiana del canto místico como expresión balbuciente de un gozo incontenible muestra, sin embargo, gran afinidad a la que esboza Jacopone en su celebrada lauda 'O iubelo del core che fai cantar d'amore' (Lauda 9 en Mancini [1980, 35-36]):

O iubelo del core,

che fai cantar d'amore!

Quanno iubel se scalda

sí fa l'omo cantare,

e la lengua barbaglia

e non sa che parlare:

dentro non pò celare

tant'è granne 'I dolzore.

Quanno iubel è acceso

sí fa l'omo clamare;

lo cor d'amore è appreso,

che nol pò comportare:

stridenno el fa gridare,

e non virgogna allore.

Quando iubelo ha preso

lo core ennamorato,

la gente l'ha 'n deriso,

pensanno el suo parlato,

parlanno esmesurato

de che sente calore.

O iubel, dulce gaudio

ched entri ne la mente

lo cor deventa savio

celar suo convenente:

non pò esser soffrente

che non faccia clamore.

Chi non ha costumanza

te reputa 'mpazzito,

vedenno esvalîanza

com'om ch'è desvanito;

dentr'ha lo cor ferito,

non se sente da fore.
También muestra una afinidad fenomenológica con esa poética afectiva de Rolle que se arraiga en fervor, dulcor y, sobre todo, canor: la expresión ante mortem del gozo paradisiaco como canciones del amor extático (e.g. "Ihesu swet, nowe wil I synge / to the a songe of loue-langynge...»)..$^{50} \mathrm{Y}$ esos desatinos teresianos no distan tampoco del mismo San Juan al definir como dislates esas "canciones ... escritas con algún fervor del amor de Dios ... los dichos de amor en inteligencia mística» que también define como frutos de "esa misma abundancia e ímpetu» (cfr. el prólogo famoso de su comentario místico al Cántico espiritual, con toda la poética que entraña sobre la insólita factura de sus versos). ${ }^{51}$

Claro que, aunque se niegue a sí misma el título de poeta por circunscribirlo instintivamente al arte de los letrados, la sofisticación de su lírica desmiente esa negativa. Veamos, para concluir, un ejemplo iluminador de la estética teresiana: su glosa poética al Canticum canticorum 2,16, «Dilectus meus mihi et ego illi» (dodi li wa-ani lo en el texto hebreo original).

\section{IV: CuANdo el dulce CAZAdor: la PoÉticA de SANTA TERESA}

No hay en el Cantar de los Cantares formulación más concisa que este quiasmo para expresar el tema central del poema teresiano: la entrega recíproca de Dios y el alma vivida en la unión amorosa. Los místicos cristianos favorecían esta cita en clave anagógica como síntesis lapidaria del epitalamio bíblico, nómina que incluye, por ejemplo, a Hadewijch quien lo cita o parafrasea nueve veces en sus poemas estróficos (3.60-63, 7.83, 12.67, 13.50, 25.9, 27.46, $34.47,36.92,38.44)$ y tres veces en su epistolario. ${ }^{52}$ La apretada glosa teresiana también se ofrece $a b$ initio como brevísimo comentario a este versículo, una exégesis lírica que dirime en pocos versos un problema medular de la teología contemplativa: la paradoja mística de la gracia infusa. ¿Quién da el primer paso, la Amada o el Amado? Los teólogos místicos en su conjunto no dudan en afirmar que Dios toma la iniciativa - que se antepone la gracia como origen primordial del desiderium supernum - capacitando la rendición deliberada del alma para esa intemporal mutualidad del amor extático. Teresa también se hace aquí eco de esta intuición, pero dramatiza sus ramificaciones con el

50 Ogilvie-Thomson 1988, 50, vv. 1-2. Sobre la centralidad de canor en la mística de Rolle, véase la discusión de Watson 1991, 69-72 y los textos ahí agavillados de sus obras principales; también su análisis de canor en Melos Amoris (Watson 1991, 171-191).

51 Ruano de la Iglesia 1989, 434-436 para el Cántico A; 565-567 para el Cántico B; también entrarían aquí como objeto de comparación las reflexiones que suscitan otros asertos juancruzianos, por ejemplo, el de la ínclita respuesta que le da a su copista Magdalena del Espíritu Santo ante el mismo Cántico espiritual: "Causándome admiración la viveza de las palabras y su hermosura y sutileza, le pregunté un día si le daba Dios aquellas palabras que tanto comprendían y adornaban, y me respondió: 'Hija, unas veces me las daba Dios y otras las buscaba yo'» (Vicente Rodríguez 2012, 365). Valiosa reflexión teórica sobre esta estética del poema místico en De Certeau (1976; 2013, 123-147); reflexiones comparativas sobre los dislates sanjuanistas y el concepto de šațț ('orilla, ribera'; šațaț 'excesivo') en el trobar clus de la literatura sufí en López Baralt 1985, 199-200.

52 Enumeración exhaustiva en McGinn 1998, 419, n.32; Mechtild también se hace eco del famoso intertexto bíblico, e.g., en FLG 1,44 (Neumann 1990-1993, 1: 29.36-37, 32.90-92) y 7,16 (Neumann 19901993, 1: 268.5-7). 
contraste cuidadoso de tiempos verbales entre el tema de apertura y las dos octavillas que lo glosan. En la redondilla de rimas cruzadas que sirve de tema inicial, la iniciativa del yo poético se nos presenta como si fuera la causa y el rapto amoroso le sucede como si fuera el efecto.

X1 Yo toda me entregué y di

$\mathrm{X} 2$ y de tal suerte he trocado

X3 que es mi Amado para mí

X4 y yo soy para mi Amado.

La entrega incondicional de la Amada en el primer octosílabo, con ese doblete sinonímico de verbos en un pretérito absoluto ("Yo toda me entregué y di»), da paso al pasado perfecto del segundo verso ("y de tal suerte he trocado"), como si dicha entrega la hubiera hecho acreedora del amor mutuo ahora vivido en ese anticipo del nunc aeternum, el presente del Cantar 2:16 parafraseado en los versos tres y cuatro («que es mi Amado para mí / y yo soy para mi Amado»). La rima cruzada de la redondilla refuerza este planteamiento hipotético. El darse al Amado lo hace suyo (X1 «dị» / X3 «para mí»), dando pie al trueque de apetencias mutuas (X2 "he trocado" / X4 "para mi Amado»), que precede en la escala contemplativa la identidad de los amantes en la unión transformante (ese estado excelso celebrado en un plano secular por Petrarca y los stilnovisti y en clave contemplativa al cantarle San Juan de la Cruz a la noche oscura ["Amada en el Amado transformada»]).

Pero la secuencia temporal de esa estrofa se invierte en las dos octavillas que la glosan con sendas variantes de una misma alegoría: la caza de amor a lo divino que vertebra su trama minimalista.

A1 Cuando el dulce Cazador A2 me tiró y dejó rendida, A3 en los brazos del Amor A4 mi alma quedó caída A5 Y cobrando nueva vida A6 de tal manera he trocado A7 que es mi Amado para mí, A8 y yo soy para mi Amado.

B1 Tiróme con una flecha B2 enherbolada de amor B3 y mi alma quedó hecha B4 una con su Criador B5 Yo ya no quiero otro amor B6 pues a mi Dios me he entregado B7 y es mi Amado para mí, B8 y yo soy para mi Amado.

En ambas octavillas, la acción verbal más remota es la iniciativa inequívoca del Cazador divino que se da, como bien notara García de la Concha, en secuencias paralelas (A1-A2 Cuando el dulce Cazador / me tiró y dejó rendida / B1-B2 Tiróme con una flecha / enherbolada de amor). Dicha iniciativa tiene consecuencias inmediatas también en paralelo (느 mi alma quedó caída / $\underline{\mathrm{B} 3}$ y mi alma quedó hecha): la caída del alma en brazos del amor (A3-A4 como apodosis de los versos previos en una oración condicional) y su unión extática con su Creador (B3-B4 como el efecto de la causa eficiente en B1-B2, formando una oración coordinada). En ambas secuencias, mi alma se vuelve el sujeto de sendos verbos pasivos (quedó caída / quedó hecha). Y los versos 5-6 de ambas estrofas - versos de transición a la cita bíblica que se repite como estribillo- remachan a su vez la inversión de tiempos y agentes de la redondilla inicial. X2 (de tal suerte he trocado) se corresponde casi verbatim con A7 (de tal manera he trocado), pero ahora como consecuencia de esa «nueva vida» proveniente según A5 de la captura del alma por su dulce Cazador. X1 (Yo toda me entregué y di) se corresponde, igualmente, con B6 (pues a mi Dios me he entregado), y de nuevo, no como causa del encuentro, mas como efecto de la saciedad (B5 Ya yo no quiero otro amor) derivada de la unión amorosa. Nótese, igualmente, la inversión de sujetos entre los dobletes de verbos pretéritos en X1 y A2 (Yo me entrequé $y$ di pero EL DULCE CAZADOR me tiró y dejó rendida)..$^{53}$

La economía verbal de esta trama abarca otros aspectos medulares del poema: e.g. la formulación minimalista de la alegoría central. Los hispanistas (López Estrada, Hatzfeld, Alonso, Darbord, García de la Concha, etc.) se han desbordado con el rastreo de precursores, fuentes y paralelos tanto seculares (Gil Vicente, Juan del Encina, Diego Ramírez Pagán, etc.) como religiosos (Lulio, Osuna, Ruysbroeck, etc.) para este motivo venerable de la poesía amatoria que reelaboran de formas distintas Santa Teresa y San Juan. ${ }^{54}$ Motivo pluriforme con variantes complejas y raíces mitopoéticas en la divinización de Cúpido, el dios niño del Amor con su carcaj y sus flechas, cuyas fuentes aducidas suelen agruparse grosso modo en dos elencos de opciones. Se suele oscilar, en cuanto a la imagen, entre la caza de cetrería («los halcones amorosos que persiguen a garzas inalcanzables» [García de la Concha]) y la caza de montería (el cazador mismo persigue a un ciervo y lo hiere con sus flechas). ${ }^{55}$ En una $u$ otra variante (venatoria o volatera), se suele interpretar al cazador que persigue como alegoría del Amado y a la presa perseguida como la Amada (Dios y el alma en clave mística), si bien se puede invertir el orden (con la amada en zaga del Amado en cacería amorosa) o incluso subvertirlo (el caso sanjuanista en el Cántico espiritual, donde el ciervo del Amado huye primero habiendo él herido a su perseguidora para luego transmutarse en el ciervo de la Amada conminada por el Esposo a un imposible Vuélvete).

Sin embargo, a los eruditos responsables por este acopio de paralelos se les escapa casi siempre un aspecto diferencial de la versión teresiana: la ausencia de comparandum para el alma cazada. No hay mención en el poema de aves voladoras ni venados silvestres como presas del Cazador, ni siquiera una alusión oblicua a la identidad metafórica del alma en esta alegoría venatoria. El andamiaje imaginativo de esta cacería se reduce aquí a dos rasgos mínimos: la mención singular del Cazador y la flecha enherbolada. Los precursores aducidos por la crítica suelen ser muy explícitos con el animal correspondiente en la caza alegórica. Contrasta incluso con la versión sanjuanista en Tras el amoroso lance, cuya explícita caza -introducida

53 La temporalidad de los verbos que dislocan la relación entre el Yo y el Otro del poema se prestan a un análisis cribado por la exégesis poética del volo místico en De Certeau 1982, 216-242.

54 Véanse López Estrada 1944, 1993; Hatzfeld 1976b, 69-75; Alonso 1958, 90-95; Darbord 1952 y García de la Concha 1978, 333-338.

55 Esta diferenciación entre el ciervo que corre y el ave que vuela se vuelve lábil como alegoría poética de la caza mística, según lo intuye, por ejemplo, el escritor mejicano Juan José Arreola en el artículo "Cérvidos» de su Bestiario al hacer del alma huidiza de San Juan ciervo volador en Tras el amoroso lance: «Fuera del espacio y del tiempo, los ciervos discurren con veloz lentitud y nadie sabe dónde se ubican mejor, si en la inmovilidad o en el movimiento que ellos combinan de tal modo que nos vemos obligados a situarlos en lo eterno ... Pieza venatoria por excelencia, todos tenemos la intención de cobrarla, aunque sea con la mirada. Y si Juan de Yepes nos dice que fue tan alto, tan alto que le dio a la caza alcance, no se está refiriendo a la paloma terrenal sino al ciervo profundo, inalcanzable y volador» (Arreola 2012, 371). 
en la redondilla y reiterada en los estribillos - se cierne en torno al vuelo ascendente del alma-pájaro a lo largo de sus cuatro octavas, si bien adoptan ambos la voz trémula del alma que habla en primera persona como presa del Amado (los precursores aducidos por la crítica proceden todos en tercera persona). Teresa en esto es más afín a la intuición poética de las dos beguinas que también le dan cabida a un abordaje económico de la caza de amor sin referente zoológico y en voces líricas alternantes entre la tercera persona en clave didáctica: e.g.

Wien minne ie van binnen scoet,

hi es van so fieren moede,

wat hi ghedoghet in wederstoet

hets hem ten besten spoede

Cuando el Amor flecha a una persona en su interior, se enorgullece hasta tal punto

que lo sufrido en la adversidad

lo estima su mayor logro.

Hadewijch, SG 13.8, vv. 65-68

(Rombauts y De Paepe 1961, 108)

y una postura autobiográfica afín a la de nuestra carmelita: e.g.

\section{Die Minne}

Das ich dich jagete, des luste mich;

das ich dich vieng, des gerte ich;

das ich dich bant, des frouwete ich mich;

do ich dich wundote, do wurde du mit mir vereinet;

so ich dir kúlinschlege gibe, so wirde ich din gewaltig.

Ich han den almehtigen got von dem himelrich getriben

und han ime benomen sin moenschlich leben

und han in mit eren sinem vatter wider gegeben,

wie wenestdu snoeder wurm moegen vor mir genesen?

Mechtild, FLG 1.3

\section{El Amor}

Cazarte me ilusionaba;

apresarte, lo que deseaba;

atarte me hizo feliz;

cuando te herí, te me uniste;

tomo posesión de ti, maza en mano.

A Dios todopoderoso, lo saqué de los cielos;

su vida como hombre, se la arrebaté;

a Su Padre con honores lo devolví;

¿y piensas, vil gusano, que te has de salvar de mí?

Bi minnen maghic al

Verwinnen mine ellendeghe noet;

Ic weet wel dat ic sal.

Doch hebbic meneghen wederstoet

Die mi doet sterven

Menich werven,

Sint minne mi ierst van binnen scoet.

Ic wille aller derven.

Tote dat mi wilt erven

Die minne int rike dat si mi boet.

A través del Amor conquisto del todo mi estado miserable, mis angustias.

Que he de prevalecer, bien lo sé, pero también he de sufrir numerosos contratiempos que tantas veces me conducen

al borde de la muerte.

Desde que el Amor por primera vez traspasó con su

flecha mis entrañas

estoy dispuesta a prescindir de todo.

Hadewijch, SG 16.4, vv.31-40

(Rombauts y De Paepe 1961, 124-126)

En una lauda dialogada entre dos frailes, Jacopone muestra una economía semejante al conjurar la imagen del que rehúye la contemplación de la Cruz con el corazón en llamas, traspasado por las flechas del Amor -el divino ballesteroallí crucificado (Lauda 2, vv. 11-22, Mancini [1980, 8]):

«Frate, eo si fugio, cà eo so' firito; venuto m'è 'I colpo, lo cor m'à partito.

Non par che tu sente de quel ch'e' ho sentito, però non me par che ne sacci parlare».

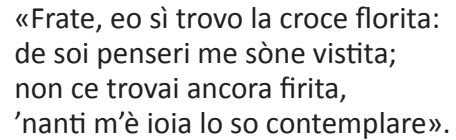

«Et eo la trovo plena de saiette, ch'esco del lato, nel cor me s'ò fitte; lo balisteri 'never me l'à diritte, onn'arme c'aio me fa perforare».

Jacopone desarrolla el tema un poco más por extenso, pero con una economía comparable en su figuración, en otra lauda semi-dialogada sobre el conflicto entre el amor verdadero y la mala discreción, con la personificación concomitante del cuerpo y la razón. Se centra también en el Amor mismo como arquero sin más atributos (Lauda 16, vv. 5-6, 26-30, 43-46 [Mancini 1980, 47-48]):

Saietta êl Cor lancia i dolcezza;

dasc'à 'I firito, 'I fa empazzare ...

L'Amore, odennol, sì saietta de gran secreto so lancetta;

la Carne 'I sente, stace afflitta, ché l'émpeto non pò portare ...

L'Amor si l'ode e non lo 'ntenne, de gran fervor su' arco tenne, saietta êl cor, tutto l'acènne del gran Signor che non n’à pare.

Pero regresemos al poema. Teresa reduce el tema de la caza a la herida recibida del Cazador con la flecha enherbolada de amor, una formulación tan sucinta como la de San Agustín en las Confesiones cuando afirma con belleza lapidaria: "Sagittaveras tu cor nostrum caritate tua» (9.2.3). Y es que este minimalismo es el centro de gravedad estético que vertebra la concentración de sus esfuerzos líricos. No hay desperdicio en esta miniatura. La alegoría venatoria se reduce a la objetivación del hecho extático en una herida de amor exenta de distracciones. ${ }^{56}$ El ritmo prosódico se con-

56 Cabría notar que algo parecido acontece con la presentación económica del Cazador sin rasgos definitorios que precisen su identidad (salvo por la rima con Criador que discutiremos más abajo). Este dulce Cazador - puede asumirse- es avatar poético del divino 
centra en el vuelo de la flecha, remachado por esa singular acentuación del verso B2 no en la primera, segunda o tercera sílaba, sino en la cuarta, la primera a de en-her-bo-lá-da que arrastra el oído atenazado en su veloz desplazamiento (es el único verso del poema con acento en la cuarta sílaba). ${ }^{57}$ No se prolonga el hecho en una cascada juancruziana de imágenes impresionistas hilvanadas como sus dislates en aras de la inefabilidad. Solo hay dos adjetivos exentos en todo el poema, ambos en paralelo en las dos mitades de la primera octava: nueva (A5) para esa vida sobre la cual rapsodiaba en Vivo sin vivir en mí, y dulce (A1), calificativo del Cazador en correspondencia puntual con la frase adjetival enherbolada de amor, la sensación implícita del amor que lleva untada en la flecha como un veneno.

Si buscásemos pistas externas en la experiencia que se le asocia -el recuento verbal de la transverberación en el Libro de la Vida 29,13- veríamos que esta dulzura del Cazador solo halla paralelo en esa suavidad excesiva de la transfixio cordis, la que profesa la santa extasiada con el dardo incandescente en las entrañas ( Era...tan excesiva la suavidad que me pone este grandísimo dolor [...] Es un requiebro tan suave que pasa entre el alma y Dios...»). ${ }^{58} \mathrm{Y}$ no solo eso. También se explicita allí el sentido alegórico de esa hierba de amor que le unta en su flecha el divino Cazador:

No procura el alma que duela esta llaga de la ausencia del Señor, sino hincan una saeta en lo más vivo de las entrañas y corazón a las veces, que no sabe el alma qué ha ni qué quiere. Bien entiende que quiere a Dios, y que la saeta parece traía hierva para aborrecerse a sí por amor de este Señor, y perdería de buena gana la vida por Él (Vida 29,10 [Madre de Dios y Steggink 1986, 157]).

La transverberación de su corazón con el dardo del ángel -episodio inmortalizado en manos de Bernini que tanto quehacer les ha dado a los psicoanalistas - gozaba de importantes precedentes en la mística amatoria cristiana. No deja de sorprender su estrecha cercanía con el comentario de Orígenes al Cantar 2:5 (Vlg.) sobre el vulnus amoris de la Amada (Comentario al Cantar de los Cantares, 3.8.13):

Si quis usquam est qui fideli hoc amore verbi Dei arsit aliquando, si quis est, ut propheta dicit, qui electi jaculi ejus dulce vulnus plagamque accepit, si quis est qui scientiae ejus amabili confixus est telo, ita ut diurnis eum desideriis nocturnisque suspiret, aliud qui loqui non possit, audire aliud nolit, cogitare aliud nesciat, desiderare praeter ipsum, aut cupere aliud vel sperare non libeat: ista anima merito dicit: Vulneratae charitatis ego sum; et ab illo vulnus accepit, de quo dixit Isaias: Et posuit me sicut jaculum electum, et in pharetra sua abscondit me. Tali vulnere decet Deum percutere animas, talibus jaculis telisque configere, ac salutaribus eas vulneribus sauciare: ut quia Deus charitas est, dicat et ipse:

Amado, pero su carencia de atributos lo hermana en estos versos con el aura de incertidumbre que reviste la esquiva evocación del ángel en el relato de la transverberación, cfr. el análisis perceptivo de «l'ange au dard» en el libro póstumo de De Certeau 2013, 274-276.

57 Si se escande en-hèr-bo-lá-da de a-mór a lo Navarro Tomás (o òo óoo ó[o]-1T1D1T), habría que decir que es el único verso en el poema cuyo primer acento primario cae en el dáctilo de un trímetro 1T1D1T con anacrusis de la primera sílaba.

58 Madre de Dios y Steggink 1986, 158.
Quia vulneratae charitatis ego sum (Patrologia Graeca 13, col. 162).

Si hay alguien que alguna vez se abrasó en este fiel amor del Verbo de Dios; si hay alguien que, como dice el profeta, ha recibido la dulce herida de su saeta escogida (Is 49,2); si hay alguien que ha sido traspasado por el dardo amoroso de su ciencia, hasta el punto de suspirar día y noche por Él, de no poder pronunciar ni querer oír otra cosa, de no saber ni gustar, pensar, desear o esperar más que a Él: esta alma con toda razón dice: Estoy herida de amor (Ct. 2,5 Vlg), y la herida la recibí de aquel de quien dice Isaías: Y me puso como saeta escogida, y me guardó en su aljaba. Es conveniente que Dios golpee a las almas con tales heridas, que las traspase con tales saetas y dardos, y que las llague con tales heridas salutíferas, para que también ellas, puesto que Dios es amor (1 Jn 4,8), puedan decir: Porque estoy herida de amor (Orígenes 1994, 237).

Gran afinidad muestra también con otro pasaje autobiográfico de la monja cisterciense belga Beatriz de Nazaret (siglo XIII) en su Seven Manieren van Minne (5, 40-49):

Ende so dunct hare, dat har adren ontplucken, ende hare bloet verwalt, ende hare march verswijnt, ende hare been vercrencken, ende hare borst verbrent, ende hare kele verdroget, so dat hare anscijn ende al har ede gevuelen der hitten van binnen, ende des orwoeds van minnen. Si geveult oec die wile, dat een gescutte geet dicwile dor hat herte toter kelende vort toten hersenen, also of si har sins gemissen soude.

Es para el alma como si sus venas reventasen, se derramase su sangre, su tuétano se agostara, sus huesos se ablandaran, ardiera su corazón y su garganta se resecase, de forma tal que su rostro y sus miembros pudieran percibir ese calor interior y esa es la locura del amor. En ese instante, ella siente una flecha que atraviesa su corazón hasta llegarle a la garganta y más allá al cerebro, como si fuera a enloquecer (traducción propia).

Hay incluso un eco distante de este motivo en el panegírico mariano de Richard Rolle, imbricado en clave mística con el de la Mater Dolorosa (Canticum amoris, vv. 93-94):

$\begin{array}{ll}\text { Lancea letificat } & \text { que mentem transfixit; } \\ \text { Amantem amplificat: } & \text { sic dilexit dicit. } .^{59}\end{array}$

Pero si contrastamos, de nuevo, su recuento gráfico y detallado en la Vida con su destilación lírica en el poema, lo que aquí prima es la economía verbal, la concentración con que se hilvana el meollo amatorio de la transverberación en su andamiaje prosódico. De las cinco rimas que lo vertebran, despunta la rima oxítona en -or, rima que enlaza cinco de sus veinte versos ( $A 1, A 3, B 2, B 4$ y $B 5)$. Esta consonancia aguda que abarca una cuarta parte del poema anuda la identidad del Cazador y del Criador con la triple reiteración de amor en una breve letanía de rimas paronomásticas: (1) el Amor con $A$ mayúscula como metonimia y personificación del divino Cazador [A3]; (2) el amor que encubre la flecha como figura poética de ese deseo de unión con que el amor propio se disuelve en aras del amor a Dios [B2]; y (3) ese otro amor - el de las criaturas, pálido reflejo del divino- que el

59 Liegey 1956, 389. Se han dado otras propuestas comparativas, por ejemplo con la estigmatización de San Francisco y la identificación subsecuente del querubín teresiano como serafín (De Certeau 2013, 275). 
alma extasiada desecha sin miramientos al abalanzarse con júbilo en los brazos de su Amado [B5]. El amor con todos estos matices se entrelaza en la fábrica verbal del poema como un encantamiento, igual que ese minne ubicuo en los poemas más exaltados de Hadewijch y Mechtild, el luf incandescente que vertebra la reescritura lírica de su Incendium Amoris en "Love is lif» de Rolle o ese amore apoteósico que se vuelve anáfora febril en los laudes místicos de Jacopone.

Soe heeft hi vol der minnen spoet

Daer minne met minnen haer minne al scincket;

Ende so wert die minne al minne volvoet,

Daer hi ghebruket der sueter minnen.

De igual manera esta plena fruición degusta el alma cuando el Amor su amor da amorosamente;

de tal manera se sacia de Amor el amante completamente

allí en el lugar donde puede saborear el dulce amor.

Hadewijch, SG 40.6, vv. 45-48

(Rombauts y De Paepe 1961, 284)

Amore, Amore, quanto tu me fai Amore, Amore, no'l pòzzo patere!

Amore, Amore, tanto me tte dài,

Amore, Amor, ben ne credo morire!

Amore, Amore, tanto preso m'ài,

Amore, Amore, famme en te transire!

Amor, dolce languire, morir plu delettoso,

Amor medecaroso, anegan'enn amore.

Amore, Amor, lo cor sì me sse spezza,

Amore, Amor, tale sente firita!

Amore, Amor, tram' e $<\mathrm{n}>$ la tua bellezza,

Amore, Amor, per te sì so' rapita;

Amore, Amor, vivere me desprezza,

Amore, Amor, l'anema teco unita!

Amor, tu si sua vira, ià non $s e<$ ' $n>$ pò partire;

per que la fai languire, tanto stregnenno, Amore?60

Jacopone, Lauda 89, vv. 267-282

(Mancini 1980, 288)

Love is poght, with gret desyre of a faire louynge; Loue [I likene] to a fyre, pat quenchen may no pynge; Loue vs clenseth of our syn, loue our bot shal brynge; Loue be kynges hert may wyn, loue of ioy may synge. ...

Love is a light birthyn, loue gladdeth yonge and olde; Loue is withoutyn pyne, as louers haue me tolde; Loue is a gostly wyne, bat maketh bigge and bolde; Of loue no thynge shal tyne pat hit in hert wil holde. Richard Rolle, Love is lif, stanzas 2 and 13 (vv. 5-8, 49-52) (Ogilvie-Thomson 1988, 42-43)

${ }^{60}$ Podrían multiplicarse los ejemplos de laude centrados en la evocación litánica del amor: Lauda 39 (Mancini 1980, 107-113) que comienza 'O Amor, devino Amore / Amor, che non èi amato!' (vv. 1-2) y da pie a toda una serie de apóstrofes al Amor encarnado en crescendo ('O Amor amativo, / Amor consumativo, // Amor conservativo / del cor che tt'à abergato!' [vv. 7-10], 'O Amore amabele, / Amore delettabele, // Amore encogetabele / sopr'onne cogitato!' [vv. 19-22], 'Amor, la tua largezza, / Amor, la gentelezza, // Amor, la tua recchezza, sopr'onn'emagenato. /// Amore grazïoso, Amore delettoso, // Amore suavetoso, ch'el core ài sazïato!' [vv. 51-58], etc.) hasta culminar en esa profesión extática 'Clama lengua e core: / Amore, Amore, Amore!' [vv. 140-141]; o Lauda 69 (Mancini 1980, 198-201), con tres versos iniciales que riman en Amore ('Oi dolze Amore / c'ài morto l'amore, / pregote che m'occide d'Amore!' [vv. 1-3]) y la repetición cuasi-zejelesca de amore en posición de rima al final de cada estrofa.
Pero a diferencia de estos místicos, propensos al exceso verbal en la mántrica efusión de sus amores, santa Teresa se refrena, tensa el arco de su minerva y contiene esa emoción que la desborda en el estuche apretado de sus versos. Sus coplas la encauzan con disciplina, la aquilatan y reducen a una luminosa quintaesencia. No hay perífrasis morosa de sus raptos en versos puramente descriptivos, nada equiparable, por ejemplo, a esas coplas seudo-teresianas sobre la transverberación que antes se le atribuían y que parecen ser, más bien, de la descalza toledana María de San José (De las internas entrañas). ${ }^{61}$ Tampoco hay en estas coplas exornos preciosistas, divagaciones oníricas ni otros arrebatos febriles de una imaginación centrífuga que se desgrana en melismas. Es aquí precisamente en donde estriba el genio literario de sus versos. Todo se subordina en Teresa a la expresión lapidaria del amor divino, esculpida en acuciantes octosílabos con la cadencia musical de un villancico y la fuerza irresistible de su verbo. No tendrán la concisión absoluta del epigrama, pero sí su contundencia. Una misma voluntad de estilo alienta su prosa y define su poética del habla llana y punzante como saetas en verso.

$$
* * * * * * *
$$

En suma: ¿por qué son tan pocos los místicos cristianos que recurren al verso en la Edad Media occidental? No tenemos una explicación incontestable para esta anomalía histórica. Pero la consagración del verso en la literatura mística española sí se impuso con una pujanza extraordinaria como modelo fecundo de escritura religiosa en los albores de la modernidad. Y en esta excelsa tradición - coronada por San Juan de la Cruz con sus «dislates» poéticos - también despuntan con luces propias las numinosas coplas de Santa Teresa.

\section{BiBLIOgRAFÍA}

Ageno, Franca, ed. 1953. Jacopone da Todi. Laudi Trattato e Detti. Firenze: Le Monnier.

Ahmed, Shahab. 2016. What is Islam? The Importance of Being Islamic. Princeton: Princeton University Press.

Alonso, Dámaso. 1958. La poesía de San Juan de la Cruz (Desde esta ladera). 3ra edición. Madrid: Aguilar.

Álvarez, Tomás. 1996a. "Autógrafos poéticos de Santa Teresa». En Estudios teresianos, 3 vol., 2, 13-20. Burgos: Editorial Monte Carmelo.

Álvarez, Tomás. 1996b. «Más autógrafos de poemas teresianos». Estudios teresianos, 3 vols., 2, 21-38. Burgos: Editorial Monte Carmelo.

Álvarez, Tomás. 1996c. "'Vivo sin vivir en mí': en los albores de la poética de Fray Juan y de la Madre Teresa». Estudios teresianos, 3 vols., 2, 39-60. Burgos: Editorial Monte Carmelo.

Álvarez, Tomás. 2002. «Poemas». En Diccionario de Santa Teresa, dir. Tomás Álvarez, 510-514. Burgos: Editorial Monte Carmelo.

Arreola, Juan José. 2012. Obras. Antología y prólogo de Saúl Yurkievich. Sexta reimpresión de la primera edición de 1995. México: FCE.

Asín Palacios, Miguel. 1933. «Un precursor hispanomusulmán de San Juan de la Cruz». Al-Andalus 1: 7-79.

61 En las internas entrañas / sentí un golpe repentino: / el blasón era divino / porque obró grandes hazañas. / Con el golpe fui herida, / y aunque la herida es mortal / y es un dolor sin igual, / es muerte que causa vida. // Si mata, ¿cómo da vida? / Si da vida, ¿cómo muere? / ¿Cómo sana cuando hiere / y se ve con Él unida? / Tiene tan divinas mañas / que en un tan acerbo trance / sale triunfal del lance, / obrando grandes hazañas. 
Asín Palacios, Miguel. 1946. «El símil de los castillos y moradas en la mística islámica y en Santa Teresa». Al-Andalus 11: 263-274.

Asín Palacios, Miguel. 1992. Tres estudios sobre pensamiento y mística hispanomusulmanes. Madrid: Hiperión.

Barrientos, Alberto, eds. 2000. Santa Teresa de Jesús. Obras completas. 5a edición. Madrid: Editorial de Espiritualidad.

Barrientos, Alberto y José Vicente Rodríguez, eds. 2011. Lira mística. Santa Teresa de Jesús y San Juan de la Cruz (Poesías completas). Introducciones de Alberto Barrientos y José Vicente Rodríguez. Madrid: Editorial de Espiritualidad.

Baruzi, Jean. 1999. Saint Jean de la Croix et le problème de l'experience mystique. Introduction d'Émile Poulat. Paris: Éditions Salvator.

Bynum, Caroline Walker. 1987. Holy Feast and Holy Fast: The Religious Significance of Food to Medieval Women. Berkeley and Los Angeles: University of California Press.

Bynum, Caroline Walker. 1992. "The Female Body and Religious Practice in the Later Middle Ages». En Fragmentation and Redemption: Essays on Gender and the Human Body in Medieval Religion, 181-238. New York: Zone Books.

Canet, José Luis. 1992. Lope de Rueda. Pasos. Madrid: Castalia.

Darbord, Michel. 1952. "Autour de la cetrería de amor de saint Jean de la Croix». Bulletin hispanique 54 (2): 203-204.

De Certeau, Michel. 1976. "L'énonciation mystique». Recherches de science religieuse 64(2): 183-215.

De Certeau, Michel. 1982. La fable mystique, 1. XVIe - XVIle siècle. París: Gallimard.

De Certeau, Michel. 2013. La fable mystique, 2. XVIe - XVIle siècle. París: Gallimard.

De Paepe, Norbert. 1967. Hadewijch Strofische Gedichten. Een studie van de minne in het kader der 12e en 13 e eeuwse mystiek en profane minnelyrik. Ghent: Secretariat van de Koninklijke Vlaamse Academie voor Taal-en Letterkunde.

Dronke, Peter. 1968. Medieval Lyric and the Rise of European Lyric. Oxford: Clarendon Press.

Dronke, Peter. 1984. Women Writers of the Middle Ages. Cambridge: Cambridge University Press.

Dronke, Peter. 1996. The Medieval Lyric. Cambridge: D.S. Brewer.

Fanger, Claire y Nicholas Watson, eds. 2015. John of Morigny. Liber florum celestis doctrine / The Flower of Heavenly Teaching. Studies and Texts. Toronto: PIMS.

Fuente, Vicente de la, ed. 1881. Obras de Santa Teresa de Jesús. 6 vols. Madrid: Compañía de Impresores y Libreros del Reino.

García, Félix, ed. 1991. Fray Luis de León. Obras completas castellanas. 5a edición aumentada. 2 vols. Madrid: BAC.

García-Asenjo, Pilar Maícas y María Enriqueta Soriano P.-Villamil, eds. 2004. La voz del silencio: poesía monástica femenina del siglo XX. Madrid: BAC.

García de la Concha, Víctor. 1978. El arte literario de Santa Teresa. Barcelona: Ariel.

García de la Concha, Víctor, Ana María Álvarez Pellitero e Isabel del Sacramento, eds. 1982. Libro de romances y coplas del Carmelo de Valladolid (c. 1590-1609). Consejo General de Castilla-León.

Girón Negrón, Luis M. 2014. «La hoguera y la mariposa: rara fortuna de una antigua metáfora en la mística española». En Una nueva visión de literatura y arte. Actas del congreso internacional de literatura mística, ed. Diana Torres Rivera, 217-267. Ponce, Puerto Rico: Pontificia Universidad Católica de Puerto Rico.

Hatzfeld, Helmut. 1976a. «Dos tipos de poesía mística. Ejemplificados en Santa Teresa y San Juan de la Cruz (Vivo sin vivir en mí)». En Estudios literarios sobre mística española, 3ra edición corregida y aumentada. 169-211. Madrid: Gredos.

Hatzfeld, Helmut. 1976b. "Influencia de Raimundo Lulio y Jan van Ruysbroeck en el lenguaje de los místicos españoles». En Estudios literarios sobre mística española, 3ra edición corregida y aumentada. 37-121. Madrid: Gredos.

Hilka, Alfons, Otto Schumann y Bernhard Bischoff, eds. 1995. Carmina Burana. Die Lieder der Benediktbeurer Handschrift. Zweisprachige Ausgabe. 6a edición revisada. Munich: Deutsche Taschenbuch Verlag.
Lapesa, Rafael. 1988. "Tradición literaria de un poema teresiano». En De Ayala a Ayala: estudios literarios y estilísticos, 141-149. Madrid: Istmo.

Liegey, Gabriel M. 1956. "The Canticum amoris of Richard Rolle». Traditio 12: 369-391.

López Baralt, Luce. 1985. San Juan de la Cruz y el Islam. México: El Colegio de México - Universidad de Puerto Rico.

López Baralt, Luce. 1989. «El símbolo de los siete castillos concéntricos del alma en Santa Teresa y el Islam». En Huellas del Islam en la literatura española: de Juan Ruiz a Juan Goytisolo, 73-97. Madrid: Hiperión.

López Baralt, Luce. 1998. Asedios a lo indecible: San Juan de la Cruz canta al éxtasis transformante. Madrid: Trotta.

López Baralt, Luce, ed. 1999. Abū-I-Hasan al-Nūrī de Bagdad. Moradas de los corazones. Madrid: Trotta.

López Baralt, Luce, ed. 2012. El canto místico de Ernesto Cardenal. Madrid: Trotta.

López Estrada, Francisco. 1944. «Una posible fuente de san Juan de la Cruz». RFE 28: 473-477.

López Estrada, Francisco. 1993. «Volando en las alturas: persecución de una imagen poética en San Juan de la Cruz». En Presencia de San Juan de la Cruz, ed. Juan Paredes Núñez, 265-289. Granada: Universidad de Granada.

Madre de Dios, Efrén de la y Otger Steggink. 1977. Tiempo y vida de Santa Teresa. 2a edición revisada y aumentada. Madrid: BAC.

Madre de Dios, Efrén de la y Otger Steggink, eds. 1986. Santa Teresa de Jesús. Obras completas. Madrid: BAC.

Mancini, Franco, ed. 1974. Iacopone da Todi. Laude. "Scrittori d'Italia» no. 257. Bari: Laterza.

Mancini, Franco, ed. 1980. Iacopone da Todi. Laude. Bari: Laterza.

Márquez Villanueva, Francisco. 1968. "Santa Teresa y el linaje». En Espiritualidad y literatura en el siglo XVI, 139-205. Madrid: Alfaguara.

Márquez Villanueva, Francisco. 1983. «La vocación literaria de Santa Teresa». Nueva Revista de Filología Hispánica 32: 355-379.

McGinn, Bernard. 1998. The Flowering of Mysticism. Men and Women in the New Mysticism - 1200-1350. New York: Cross Road.

McGinn, Bernard. 2012. The Varieties of Vernacular Mysticism (13501550). New York: Cross Road.

Morris, C. Brian. 1986. "The Poetry of Santa Teresa». Hispania 69(2): 244-250.

Navarro Tomás, Tomás. 1974. Métrica española. Madrid - Barcelona: Guadarrama.

Neumann, Hans, ed. 1990-1993. Mechtild von Magdeburg. Das fließende Licht der Gottheit. 2 vols. (Band I: Text; Band II: Untersuchungen). Munich: Artemis Verlag.

Newman, Barbara. 1995. From Virile Woman to WomanChrist. Studies in Medieval Religion and Literature. Philadelphia: University of Pennsylvania Press.

Nicholson, Reynold, ed. 1914. Abū Nașr 'Abdallah B. 'Alī al-Sarrāj al-Țūsī, The 'Kitāb al-Luma' fi 'I-tașawwuf. Edición anotada con glosario, índice y resumen del contenido. Leiden: Brill - Londres: Luzac.

Ogilvie-Thomson, Sarah J., ed. 1988. Richard Rolle: Prose and Verse (Edited from MS Longleat 29 and Related Manuscripts). London: The Early English Text Society y Oxford University Press.

Orígenes. 1994. Comentario al Cantar de los Cantares. Introducción y notas Manlio Simonetti y traductor Argimiro Velasco Delgado O.P. Madrid: Editorial Ciudad Nueva.

Orozco Díaz, Emilio. 1994. "Poesía carmelitana tradicional». En Estudios sobre San Juan de la Cruz y la mística del barroco. Ed. José Lara Garrido, 2 vols., 1, 143-194. Granada: Universidad de Granada.

Peck, Gregory. 1980. The Fool of God: Jacopone da Todi. University of Alabama Press.

Pertile, Lino. 1998. La puttana e il gigante. Del Cantico dei Cantici al Paradiso terrestre di Dante. Ravenna: Longo.

Pertile, Lino. 2005. La punta del disio. Semantica del desiderio nella Commedia. Firenze: Cadmo. 
Reynaert, Joris. 1976. "Het doodsmotief bij Hadewijch». Studia Germanica Gandensia 17: 5-18.

Reynaert, Joris. 1994. «Hadewijch: Mystic Poetry and Courtly Love». En Medieval Dutch Literature in its European Context, ed. Erik Kooper, 208-225. Cambridge: Cambridge UP.

Rombauts, E. y Norbert De Paepe, eds. 1961. Hadewijch. Strofische Gedichten: Middelnederlandse tekst en moderne bewerking met een inleiding. Zwolle: Willink.

Ruano de la Iglesia, Lucinio, ed. 1989. San Juan de la Cruz. Obras completas. 12 ma edición. Madrid: BAC.

Ruh, Kurt. 1993. Geschichte der abendländische Mystik. Band II, Frauenmystik und Franziskaniche Mystik der Fruhzeit. Munich: Beck.

Schimmel, Annemarie. 1975. Mystical Dimensions of Islam. Chapel Hill: University of North Carolina Press.

Schimmel, Annemarie. 1982. As Through a Veil: Mystical Poetry in Islam. New York: Columbia University Press.

Serés, Guillermo. 1996. La transformación de los amantes. Imágenes del Amor de la Antigüedad al Siglo de Oro. Barcelona: Crítica.

Thompson, Colin. 2003. St. John of the Cross: Songs in the Night. Washington DC: Catholic University of America Press.

Tobin, Frank, ed. y trad. 1998. Mechtild of Magdeburg. The Flowing Light of the Godhead. New York: Paulist Press.

Ugofsky-Méndez, Rubí. 2014. Voces femeninas españolas desde dentro. El discurso masculino reconfigurado por mujeres en El libro de romances y coplas del Carmelo de Valladolid (c. 1590-1609). Frankfurt am Main: Peter Lang.

Underhill, Evelyn. 1919. Jacopone da Todi, Poet and Mystic 1228-1306. Londres: Dent.
Van Mierlo, Joseph, ed. 1924-1925. Hadewijch. Visioenen. 2 vols. Louvain: Vlaamsch Boekenhalle.

Van Mierlo, Joseph, ed. 1942. Hadewijch. Strophische Gedichten. 2 vols. Antwerp: N.V. Standaard.

Van Mierlo, Joseph, ed. 1947. Hadewijch. Brieven. 2 vols. Antwerp: N.V. Standaard.

Van Mierlo, Joseph, ed. 1952. Hadewijch. Mengeldichten. Antwerp: N.V. Standaard.

Vega, Ángel Custodio. 1975. La poesía de Santa Teresa. 2ạ. edición. Madrid: BAC.

Vicente Rodríguez, José. 2012. San Juan de la Cruz: la biografía. Madrid: San Pablo.

Vicente Rodríguez, José. 2013-2014. «Nada te turbe, / nada te espante ... (Parte I)". San Juan de la Cruz 48: 323-332.

Vicente Rodríguez, José. 2015. «Nada te turbe, / nada te espante ... (Parte II)». San Juan de la Cruz 49: 155-162.

Wainwright-deKadt, Elizabeth. 1980. "Courtly Literature and Mysticism: Some Aspects of Their Interaction». Acta Germanica 12: 41-60.

Watson, Nicholas. 1991. Richard Rolle and the Invention of Authority. Cambridge: University of Cambridge Press.

Watson, Nicholas. 1999. "Desire for the Past». Studies in the Age of Chaucer 21: 59-97.

Weber, Alison. 1990. Teresa of Avila and the Rhetoric of Femininity. Princeton: Princeton University Press.

Wilmart, André. 1933. "Les traités de Gérard de Liège sur l'amour illicite et sur l'amour de Dieu». En Analecta Reginensia, 205-247. Roma: BAV. 